BERNARDI, ALESSANDRO. "Seguridad y Derecho Penal en Italia y en la Unión Europea".

Polít. crim. Vol. 5, № 9 (Julio 2010), Art. 2, pp. 68-113.

[http://www.politicacriminal.cl/Vol_05/n_09/Vol5N9A2.pdf]

\title{
Seguridad y Derecho Penal en Italia y en la Unión Europea *
}

\author{
Alessandro Bernardi \\ Catedrático de Derecho Penal, Universidad de Ferrara, Italia. \\ brn@unife.it
}

\section{Resumen}

El autor ofrece un panorama completo de las relaciones existentes entre seguridad y derecho penal, tanto en Italia como en la Unión Europea. Para ello desarrolla primero un marco conceptual, en el que distingue básicamente dos acepciones de la idea de "seguridad": una menos liberal, vinculada a la idea de "seguridad pública", entendiendo la seguridad como un fin que justificaría limitaciones a los derechos y libertades; y una acepción más liberal, que entiende la seguridad como un bien merecedor de protección o como un derecho de las personas. A continuación, el autor ilustra el modo en el que dichas concepciones se han plasmado en concreto, comparativamente, en la política criminal italiana y de la Unión Europea (haciéndose cargo de la situación legislativa y jurisprudencial), para concluir con una toma de posición personal, favorable en general a una concepción más liberal de seguridad en el campo penal.

\section{Palabras clave}

Seguridad, política criminal, derechos fundamentales, terrorismo, delincuencia común, Unión Europea, Italia.

\begin{abstract}
The author presents a complete overview of the existing relationships between security and penal law, both in Italy and in the European Union; firstly, by developing the conceptual framework, in which he primarily distinguishes two meanings of the idea of "security": a less liberal one, connected to the idea of "public security", understanding security as an end that would justify curtailing rights and liberties; and a more liberal one, that understands security as a good deserving of protection or as a right of citizens. Then, the author illustrates the way in which these meanings have been formalized, comparatively, in Italian and the European Union's criminal policies (by analyzing the legislative and judicial situations), and concludes with his personal point of view, in favor of a more liberal meaning of security in criminal law.
\end{abstract}

\section{Key words}

Security, criminal policy, fundamental rights, terrorism, common delinquency, European Union, Italy. 
Sumario: 1. Premisa. - 2. La seguridad como límite a los derechos y a las libertades fundamentales en la experiencia italiana. - 3. La seguridad como límite a los derechos y a las libertades fundamentales en las Cartas de Derechos, y en particular en la Convención europea de los derechos del hombre. - 4. La connotación "pública" de la seguridad entendida como límite a los derechos y a las libertades fundamentales. Las diversas acepciones de la idea de "seguridad pública". - 5. Los riesgos de involución autoritaria implícitos en la valorización de la seguridad pública en función limitadora de derechos/libertades fundamentales. Los remedios por la Constitución italiana y por las Cartas europeas de derechos. - 6. La seguridad como derecho fundamental en la Constitución italiana y en las Cartas de derechos. Su carácter de "derecho instrumental" o de "derecho final". - 7. La seguridad como derecho a la protección de intromisiones de los poderes públicos y su función antagonista respecto a los efectos liberticidas de la "seguridad pública". - 8. La seguridad como derecho a ser tutelados frente a los "riesgos criminales". Sus perspectivas y posibles efectos a nivel constitucional y europeo. - 9. La seguridad frente a la criminalidad, como objeto de la política criminal italiana y europea. 10. La política criminal italiana en materia de seguridad. En particular, la lucha "selectiva" contra las formas de macro-criminalidad. - 11. La política judicial italiana a favor de la seguridad contra la "maxi-criminalidad". En particular, la dilatación de la responsabilidad penal por los delitos de terrorismo y mafia y el progresivo abandono de la oposición a la criminalidad económico-política - 12. La política criminal italiana en materia de seguridad privada: la lucha contra la criminalidad callejera. - 13. La política criminal europea en materia de seguridad. El rol del Consejo de Europa y de la Unión Europea. - 14. El rol de la Corte de Justicia UE en la concretización de la política criminal europea. - 15. Consideraciones conclusivas.

\section{Premisa.}

Las relaciones entre seguridad y derecho penal son extremadamente complejas y contradictorias; esto es así sobre todo si se considera que el concepto mismo de seguridad resulta escurridizo1 y aún "anfibiológico". En todo caso, para una primera aproximación conviene destacar que la seguridad puede ser entendida tanto en sentido negativo (es decir, como un fin que justificaría limitaciones a los derechos/libertades), como en sentido positivo (es decir, como un derecho o, al menos, como un bien merecedor de protección).

Entendida en sentido negativo, la seguridad asume un carácter eminentemente público (propio del derecho público): siendo un fin esencial del Estado la auto-preservación, tanto en cuanto institución como en cuanto colectividad de sujetos, ella se alcanza no sólo prohibiendo comportamientos considerados dañinos, sino también colocando límites a las

\footnotetext{
* El texto aquí traducido desde el italiano corresponde a la conferencia preparada especialmente por el Prof. Alessandro Bernardi para el Seminario Internacional sobre Seguridad y Derecho Penal, organizado por el Centro de Estudios de Derecho Penal de la Universidad de Talca y que se realizó en Santiago de Chile los días 13 y 14 de noviembre de 2008. La presente traducción fue realizada por el Dr. Fernando Londoño M. sobre la base del texto original de la conferencia, el que sería posteriormente complementado por su autor mediante la incorporación de un aparato mayor de notas bibliográficas.

${ }^{1}$ Cfr., por ejemplo, PIZZIMENTI, Eugenio; VANNUCCI, Alberto, "Il concetto di sicurezza e le politiche per la sicurezza", Riv. trim. scienza amm., 2005, n. 4, pp. 51 y ss.
} 
Polít. crim. Vol. 5, № 9 (Julio 2010), Art. 2, pp. 68-113.

[http://www.politicacriminal.cl/Vol_05/n_09/Vol5N9A2.pdf]

libertades fundamentales. Entendida la seguridad en sentido positivo, ella asume un carácter eminentemente privado, constituyendo un derecho de los sujetos el de ser tutelados, tanto de cara al Estado como de cara a otros sujetos.

Por otra parte, los vínculos que se dan entre la seguridad entendida como límite a los derechos y la seguridad como derecho, resultan a veces - como veremos - estrechísimos. En todas sus diversas acepciones, la seguridad es en todo caso perseguida también $-\mathrm{y}$ quizás, ante todo - a través del derecho penal, y constituye uno de los objetivos principales de la política criminal. En esta conferencia intentaré, precisamente, sintetizar las relaciones existentes entre seguridad y derecho penal en Italia y en la Unión Europea, atendiendo a los diversos perfiles o contornos que la seguridad asume en lo específico.

\section{La seguridad como límite a los derechos y a las libertades fundamentales en la experiencia italiana.}

En Italia la seguridad ha sido tradicionalmente considerada, antes que nada, como una finalidad que justifica limitaciones a la libertad en sus diversas formas; seguridad, por tanto, como límite a los derechos individuales, incluyendo aquellos de matriz constitucional.

En nuestra Constitución Republicana de 1948 - actualmente vigente - (CPR, en lo sucesivo) esta concepción está muy presente. Así, por ejemplo, conforme al art. 16 de la CPR, por motivos de seguridad se pueden adoptar limitaciones a la libertad de circulación; y sobre la base del art. 17 CPR, siempre por motivos de seguridad, el derecho de reunión en lugares públicos puede ser sujeto a limitaciones.

Sin embargo la aludida concepción no aparece necesariamente sostenida por normas constitucionales que contemplen las correspondientes limitaciones a los derechos. De hecho, sobre la base de la denominada teoría de los límites implícitos a los derechos y a las libertades fundamentales, ${ }^{2}$ la Corte Constitucional italiana admite - por vía interpretativa que limitaciones a tales derechos y libertades puedan subsistir aun cuando no estén expresamente previstas: lo anterior siempre que, es preciso aclararlo, las referidas limitaciones resulten, conforme a un juicio de balance, justificables a la luz de otro interés constitucionalmente relevante o bien a la luz del sistema constitucional en su conjunto. ${ }^{3}$ Ahora bien, al interés constituido por la seguridad \{del Estado y de la colectividad\} se le atribuye, precisamente, una importancia tal como para justificar, en ocasiones, medidas restrictivas de derechos/libertades individuales. De hecho, en algunos momentos particularmente difíciles de nuestra historia republicana, la Corte Constitucional ha reconocido la legitimidad de leyes que preveían macroscópicas restricciones de los

\footnotetext{
${ }^{2}$ Cfr., por todos, PALAZZO, Francesco; BERNARDI, Alessandro, "La Convenzione europea dei diritti dell'uomo e la politica criminale italiana: intersezioni e lontananze", Rivista internazionale dei diritti dell'uomo, 1988, p. 50.

${ }^{3}$ Cfr., en particular, Corte Const., 7 mayo 1975, n. 102. En doctrina, cfr., por todos, BARILE, Paolo, Diritti dell'uomo e libertà fondamentali, Boloña: 1984, pp. 42 y ss.
} 
derechos individuales, incluso si no estaban previstas por la Constitución; ${ }^{4}$ por ejemplo, con el fin de alcanzar la seguridad mediante la prevención de delitos graves, ${ }^{5}$ fueron autorizadas interceptaciones telefónicas preventivas, ${ }^{6}$ las que derogaban el principio de "inviolabilidad de la correspondencia y de toda otra forma de comunicación” (art. $15 \mathrm{CPR}$ ); un principio que la Constitución no prevé explícitamente como limitable por razones de seguridad.

Análogamente, y siempre por motivos de seguridad, ulteriores limitaciones y restricciones de diverso tipo podrían introducirse en el futuro a los derechos/libertades constitucionales. Por otra parte, es pacífico que la violación de las referidas limitaciones puede ser castigada por vía del recurso a sanciones penales, si bien siempre en el respeto del principio de extrema ratio. ${ }^{7}$

En síntesis, el sistema constitucional italiano admite que por razones de seguridad \{pública\} puedan limitarse derechos/libertades fundamentales y puedan aplicarse sanciones penales contra quienes ejerciten tales derechos/libertades en violación de las limitaciones del caso.

\section{La seguridad como límite a los derechos y a las libertades fundamentales en las Cartas de Derechos, y en particular en la Convención europea de los derechos del hombre.}

La seguridad concebida como límite a los derechos y a las libertades fundamentales asume relevancia también en el plano de las fuentes internacionales. Basta recordar el Pacto Internacional sobre los derechos civiles y políticos de 1966, el que admite que por motivos de seguridad se puedan restringir la libertad de movimiento y de residencia (art. 12), la libertad de pensamiento, conciencia y religión (art. 18), la libertad de opinión y de expresión (art. 19), el derecho a reunión pacífica (art. 21), y la libertad de asociación (art. 22).

Aun más interesante, especialmente en el ámbito de la presente conferencia, resulta constatar cómo la seguridad puede incidir en derechos/libertades previstos en textos normativos emanados de organizaciones internacionales del continente europeo. A este respecto resulta fundamental la revisión de la Convención europea de los derechos del hombre de 1950 (CEDU, en lo sucesivo). Este texto no sólo constituye el más conocido e importante entre los tratados multilaterales hasta hoy predispuestos bajo el alero del

\footnotetext{
4 Por lo demás, en esto la Corte constitucional italiana no se ha apartado de una praxis difundida prácticamente en todas partes. Cfr. BIN, Roberto, "Democrazia e terrorismo", en: DE MAGLIE, Cristina; SEMINARA, Sergio (coord.), Terrorismo internazionale e diritto penale, Padua: 2007, pp. 39 y ss.

${ }^{5}$ Delitos indicados en el inciso primero del art. 165 ter c.p.p.

${ }^{6}$ Cfr. ILLUMINATI, Giulio, La disciplina processuale delle intercettazioni telefoniche, Milano: 1983, pp. 171 y ss.; SIGNORINO, Domenico, "Intercettazioni telefoniche", en: VASSALLI, Giuliano (coord.), Dizionario di diritto e procedura penale, Milán: 1986, pp. 505 y ss.

${ }^{7}$ Conforme a dicho principio, debe recurrirse a la sanción penal cuando resulte absolutamente indispensable en el plano de la proporcionalidad y de la subsidiariedad; es decir, cuando una sanción de otro tipo (administrativa o civil) resultaría desproporcionada por defecto e inadecuada para prevenir eficazmente los comportamientos prohibidos.
} 
Polit. crim. Vol. 5, No 9 (Julio 2010), Art. 2, pp. 68-113.

[http://www.politicacriminal.cl/Vol_05/n_09/Vol5N9A2.pdf]

Consejo de Europa $^{8}$ con miras a la tutela de los derechos fundamentales en los países miembros, sino que también aparece como el tratado que mayormente está en condiciones en la legislación de dichos países. De hecho, los principios de la CEDU prevalecen por sobre las normas nacionales (incluidas las penales) derogadoras de dichos principios, de manera que constituyen un conjunto de principios superiores respecto a las leyes ordinarias de los Estados miembros. A través de la CEDU y de su Corte, ${ }^{9}$ compuesta por un número de jueces correspondiente al número de Estados miembros, ${ }^{10}$ se realiza una suerte de "justicia constitucional supra-nacional", 11 que integra y complementa las formas de control constitucional eventualmente previstas en cada uno de los Estados que adhieren a la CEDU. $^{12}$

Dicho todo lo anterior, se hace necesario precisar que, sobre la base de la CEDU, varios de los principales derechos/libertades en ella reconocidos - el derecho al respeto de la vida privada y familiar (art. 8), la libertad de pensamiento, de conciencia y de religión (art. 9), la libertad de expresión (art. 10), la libertad de reunión y de asociación (art. 11) - pueden ser limitados por razones de seguridad nacional y/o de orden público (concepto éste difícilmente distinguible del de seguridad nacional, y en todo caso expresivo - en principio - del conjunto de las normas fundamentales del Estado, ${ }^{13}$ de la estructura que asegura su general buen funcionamiento). ${ }^{14}$ Además, como veremos mejor a continuación, incluso el derecho a la vida contemplado en el art. 2 CEDU y el derecho de libertad/seguridad personal previsto en el art. 5 CEDU pueden ser limitados por razones reconducibles a un concepto general de seguridad: por ejemplo, para asegurar la defensa contra violencias ilegales ${ }^{15}$ o bien para prevenir la comisión de delitos. ${ }^{16}$

En conclusión, la CEDU permite que, por exigencias de seguridad, los mencionados derechos/libertades en ella reconocidos sean sujetos a límites en las legislaciones

\footnotetext{
${ }^{8}$ Como apreciaremos mejor infra, par. 9, el Consejo de Europa tiene como finalidad procurar una unión más estrecha entre sus países miembros, en particular favoreciendo la creación de un espacio democrático y jurídico común destinado a tutelar los derechos humanos.

${ }_{9}^{9}$ Así como, por lo demás, a través del derecho de la Unión Europea y la Corte de Justicia UE, con respecto a la cual cfr., en particular, infra, par. 14.

10 Los que actualmente son cuarenta y siete. Para una nómina actualizada cfr. http://conventions.coe.int/Treaty/Commun/ChercheSig.asp?NT=005\&CM=1\&DF=\&CL=ITA.

${ }^{11}$ Cfr. CAPPELLETTI, Mauro, "Giustizia costituzionale soprannazionale”, Riv. dir. proc., 1978, pp. 1 y ss.

${ }^{12}$ Al respecto, para mayor profundización, cfr. MASTROIANNI, Roberto, "La sentenza della Corte cost. n. 39 del 2008 in tema di rapporti tra leggi ordinarie e CEDU: anche le leggi cronologicamente precedenti vanno rimosse dalla Corte costituzionale?", http://www.giurcost.org/decisioni/index.html; SCIARABBA, Vincenzo, "Il problema dei rapporti tra (leggi di esecuzione di) vincoli internazionali e leggi precedenti nel quadro della recente giurisprudenza costituzionale, http://www.giurcost.org/decisioni/index.html

${ }^{13}$ PALADIN, “Ordine Pubblico” (voz), en: N.ssimo Dig. it., XII, Turín, 1965.

${ }^{14}$ Es cierto que, en el lenguaje jurídico italiano, resulta difícil distinguir entre el concepto de seguridad pública y el de orden público, en cuanto ambos términos son frecuentemente usados como sinónimos. En este sentido, el segundo de dichos conceptos también presenta la multiplicidad de acepciones propias del primero. Cfr., ampliamente y de reciente, ANGELINI, Francesca, Ordine pubblico e integrazione costituzionale europea, Padua: 2007, p. 1, según la cual 'l'ordine pubblico si presenta come una 'figura enigmatica' priva di definizione" [ndt: "el orden público se presenta como una 'figura enigmática', carente de definición”].

${ }^{15}$ Cfr. art. 2, par. 2, letra a) CEDU.

${ }^{16}$ Cfr. art. 5, par. 2, letra c) CEDU.
} 
nacionales, si es del caso también previendo sanciones penales en supuestos de violación de dichos límites.

Por otra parte es cierto que las limitaciones que la CEDU admite por razones de seguridad conforme a los arts. 8, 9, 10 y 11 , no son entregadas a la total discrecionalidad de los legisladores de los países miembros; por el contrario, como es precisado en los mismos artículos antes mencionados, tales limitaciones son consentidas sólo cuando ellas "constituyan medidas necesarias en una sociedad democrática". Esta cláusula, denominada precisamente "de democracia", permite tanto circunscribir por vía interpretativa las finalidades con mira a las cuales los correspondientes derechos pueden ser limitados, así como elaborar un principio general de proporcionalidad, útil para efectos de un juicio de balance entre los derechos-libertades solemnemente proclamados en la CEDU y las razones de seguridad nacional y/o de orden público que podrían justificar la limitación de tales derechos-libertades al interior de cada Estado. ${ }^{17}$

\section{La connotación "pública" de la seguridad entendida como límite a los derechos y a las libertades fundamentales. Las diversas acepciones de la idea de "seguridad pública".}

A esta altura cabe subrayar que la seguridad - allí donde sea entendida como finalidad pública idónea para limitar los derechos y las libertades fundamentales y, por tanto, como "seguridad pública" - tiende a asumir significados parcialmente diversos.

En primer lugar, parece posible distinguir entre una seguridad pública en sentido estatalista o bien "europeísta"; en segundo lugar, entre una seguridad pública de las instituciones o bien de los ciudadanos a ellas referidos.

\subsection{Seguridad pública en el sentido estatalista.}

Por lo que se refiere a la seguridad pública en el sentido estatalista, ella alude en realidad a un concepto de seguridad pública circunscrito a nivel nacional.

En este sentido, la "seguridad pública" podría aludir tanto a la seguridad del Estado en cuanto tal (a) como a la de la comunidad por aquél comprendida: quiere decir, a la seguridad de la población que reside en el espacio comprendido por el Estado (b).

a) Conforme a la primera perspectiva, la seguridad pública guarda relación ante todo con la existencia, integridad e independencia del Estado en su dimensión institucional, ${ }^{18}$ y expresa por tanto una exigencia de protección del aparato estatal, un interés propio del Estado

\footnotetext{
17 Cfr., amplius, PALAZZO, Francesco; BERNARDI, Alessandro, "La Convenzione europea dei diritti dell'uomo e la politica criminale italiana: intersezioni e lontananze", Rivista internazionale dei diritti dell'uomo, 1988, pp. 53 y ss., y la bibliografía allí citada.

${ }^{18} \mathrm{Y}$ aun derechamente con su dimensión geográfica (como en el caso de la "seguridad de los límites nacionales").
} 
Polit. crim. Vol. 5, No 9 (Julio 2010), Art. 2, pp. 68-113.

[http://www.politicacriminal.cl/Vol_05/n_09/Vol5N9A2.pdf]

considerado en sí mismo. ${ }^{19}$ Tal interés ha sido sólo recientemente asumido de manera explícita en la Constitución italiana, ${ }^{20}$ la que, por otra parte, en principio no toma en consideración una idea de seguridad dirigida a preservar un modelo de Estado particular, pensado como "superior" a otros y en vista de cuya tutela consentir limitaciones a los derechos/libertades constitucionalmente garantizados.

b) Conforme a la segunda perspectiva, la seguridad pública no dice relación con la tutela del Estado en cuanto tal, pero tampoco atañe a la tutela de un sujeto particular o de algunos sujetos que habitan en el espacio ocupado por el Estado; sino que más bien guarda relación con la salvaguardia de un número indeterminado y potencialmente ilimitado de individuos pertenecientes al Estado en cuestión y/o de los bienes a ellos relacionados. La seguridad pública por tanto se configura como un "interés colectivo, de carácter general, referido a la colectividad". ${ }^{21}$ En realidad, este segundo concepto de seguridad pública parece corresponder al prioritariamente recogido tanto por la Constitución italiana ${ }^{22}$ como por la propia CEDU. $^{23}$

En todo caso, en ambas perspectivas la seguridad pública (entendida, precisamente, de manera restrictiva) es reconocida como algo absolutamente esencial para el Estado. En su nombre, en razón de la presunta primacía del interés público a la seguridad por sobre otros intereses y aún por sobre los derechos/libertades de los particulares, tienden a ser predispuestas y justificadas algunas compresiones de los derechos y de las libertades fundamentales. ${ }^{24}$

\subsection{Seguridad pública en sentido europeísta.}

Por lo que en cambio concierne a la seguridad pública en sentido europeista, ella en realidad alude a un concepto de seguridad pública extendido en perspectiva supra-estatal, es decir, dirigido a comprender a todos los países de la Unión, asumiendo así el carácter de

\footnotetext{
${ }^{19}$ Esta concepción "política” de orden público caracterizó, esencialmente, la experiencia italiana en la época fascista.

${ }^{20}$ De hecho, la concepción "institucional" de orden público ha sido recientemente recogida en la nueva formulación (efectuada en 2001) del art. 117, inc. $2^{\circ}$, letra d), de la Constitución de 1948.

${ }^{21}$ RAIMONDI, Salvatore, "Per l'affermazione della sicurezza pubblica come diritto", Dir. Amm., 2006, p. 752.

22 De hecho, en la Constitución italiana los términos "seguridad" o "incolumidad pública" se utilizan primeramente en los artículos 17 y 17 como sinónimos de orden público "material”; se trata éste de un tipo de orden que tutela sólo la incolumidad de las personas físicas o de las cosas (sobre el punto, cfr., por todos, CORSO, Guido, voce "Ordine pubblico (dir. pubbl.)", en: Enc. dir., Milán: 1980, XXX, pp. 105 y ss.; FIORE, I reati di opinione, Padova: 1972, passim; PACE, Alessandro, "Il concetto di ordine pubblico", Arch. Giur., 1963, pp. 111 y ss.). Un uso análogo del término "seguridad" es realizado también en el art. 117 inc. $2^{\circ}$, letra $h$ ) de la Const., íntegramente reformulado en 2001, según se ha dicho recién (cfr. supra nota 20).

${ }^{23}$ En efecto, según se ha mencionado (cfr., supra, parag. 3, nota 17), la concepción liberal de democracia que se obtiene a partir de la CEDU parece sugerir una interpretación restrictiva de todas las razones fundantes de límites a los derechos fundamentales. Por tanto, sobre la base de las normas CEDU la seguridad debería poder incidir sólo si referida a las personas y a las cosas (es decir, si es considerada - según la terminología italiana - equivalente al orden público "material", de ordre dans la rue). No debería en cambio ser relevante si referida a principios políticos y jurídicos (por tanto, si considerada - según la terminología italiana equivalente al orden público "ideal”).

${ }^{24}$ Cfr., en particular, Corte const., 16 de marzo de 1962, n. 19, Giur. cost., 1962, pp. 190 y ss.
} 
"seguridad común". 25 De manera más precisa, paralelamente a lo dicho recién en perspectiva estatal, la seguridad pública entendida como "seguridad común" podría aludir tanto a la seguridad de la Unión europea en cuanto tal (a) como a la comunidad comprendida en ella, es decir, al conjunto de sujetos que en ella residen y circulan (b).

a).- Conforme a la primera perspectiva, la "seguridad común" concierne a la Unión europea en su dimensión político-institucional.

b).- Conforme a la segunda perspectiva, la "seguridad común" se dirige a los sujetos que forman parte de la Unión europea, a los "ciudadanos europeos". Esta parece ser en realidad la idea de seguridad común privilegiada. ${ }^{26}$

Considérese además que en el Tratado de la Unión Europea (comenzando por su preámbulo) abundan normas que, por una parte, muestran con claridad hasta qué punto la actuación de una política de seguridad común constituye uno de los objetivos prioritarios de la Unión y que, por la otra, dejan en evidencia que el concepto de seguridad común puede asumir diferentes matices. En particular, el artículo 11 del Tratado UE afirma textualmente que, en el ámbito del mismo Tratado, buscar la seguridad común significa tender al "reforzamiento de la seguridad de la Unión en todas sus formas"; 27 incluyendo aquellas formas cuya realización se alcanza a través de la restricción de derechos/libertades fundamentales.

\section{Los riesgos de involución autoritaria implícitos en la valorización de la seguridad pública en función limitadora de derechos/libertades fundamentales. Los remedios por la Constitución italiana y por las Cartas europeas de derechos.}

Con el avance de la concepción personalista y liberal dirigida a afirmar la centralidad de la persona, la tendencia a comprimir los derechos fundamentales del individuo por razones de seguridad pública suscita siempre mayor perplejidad y temores. Temores tanto más fuertes allí donde se considere que la promulgación de leyes dirigidas a comprimir los derechos en nombre de la seguridad pública ${ }^{28}$ implica siempre un riesgo de una involución autoritaria del Estado liberal; evolución que no alcanza a ser evitada con la sola naturaleza democrática del poder legislativo.

\footnotetext{
25 Sobre el progresivo surgimiento de un "orden público europeo", cfr. ANGELINI, Francesca, Ordine pubblico e integrazione costituzionale europea, Padova: 2007, pp. 14 y ss.

${ }^{26}$ Cfr., de reciente, Consejo de la Unión Europa, Conclusiones del Consejo sobre el principio de convergencia y la estructuración de la seguridad interior, sesión N. 2899 del Consejo de Justicia y Asuntos de Interior, Luxemburgo, 24 octubre 2008, considerando $6^{\circ}$.

${ }^{27}$ VAN DE KERCHOVE, Michel, "Introduction", en: VAN DE KERCHOVE \& WEYEMBERGH, Anne, (coord.), Sécurité et justice: enjeu de la politique extérieure de l'Union européenne, Bruxelles: 2003, p. 5. Sobre los conceptos de seguridad interior y de seguridad exterior de la Unión Europea cfr., por todos, DUTHEIL DE LA ROCHERE, Jacqueline, "Vers une conception nouvelle de la sécurité européenne", Rivista italiana di diritto pubblico, 2008, en particular pp. 20 y ss.

${ }^{28}$ Especialmente si entendida en la acepción de seguridad pública "ideal” ; al respecto cfr. supra, par. 4, nota 23.
} 
Polít. crim. Vol. 5, № 9 (Julio 2010), Art. 2, pp. 68-113.

[http://www.politicacriminal.cl/Vol_05/n_09/Vol5N9A2.pdf]

En los países europeos el reconocimiento de este riesgo ha sin duda contribuido a atribuir un rol central a las Constituciones, a las Cortes constitucionales (que asumen el rol de "jueces de las leyes" y de su legitimidad) y a las Cortes internacionales de derechos. En virtud de su común connotación "personalista", de hecho, tanto la Constitución como las mencionadas Cartas internacionales son capaces de contener los super-poderes de los legisladores y de los gobiernos nacionales y de limitar su tendencia a comprimir los derechos individuales en nombre del interés público, incluso si se tratare del interés en la seguridad pública.

Esta afirmación podría parecer paradójica si se considera que - como antes he recordado en ambas categorías de textos de derecho primario existen algunas normas en las que se admite que por razones de seguridad pública puedan comprimirse los derechos y las libertades fundamentales. Pero también se ha ya recordado ${ }^{29}$ que, tanto a nivel constitucional como a nivel CEDU, dichas limitaciones no pueden asumir un carácter indiscriminado, sino que, por el contrario, hallan límites - de naturaleza normativa e interpretativa - expresivos de un principio general de proporcionalidad.

\section{La seguridad como derecho fundamental en la Constitución italiana y en las Cartas de derechos. Su carácter de "derecho instrumental" o de "derecho final".}

Por otra parte - como se subrayó a título de premisa - tanto a nivel de Constitución italiana como de Carta internacional de derechos, la seguridad no es considerada sólo en una óptica de derecho público, como restrictiva de los derechos/libertades, sino también en una óptica contrapuesta, propia de derecho privado. Conforme a esta segunda óptica, por tanto, la seguridad constituye un instrumento idóneo para garantizar de mejor manera los derechos y las libertades fundamentales de los individuos, o bien constituye ella misma un bien perseguible, cuando no ya un verdadero y propio derecho fundamental. ${ }^{30}$ De todas formas, en ambos casos - como veremos mejor a continuación - ella tiende a contrabalancear la seguridad pública y sus efectos limitadores de derechos/libertades.

Lo cierto es que en la Constitución italiana no existe una norma que prevea el derecho de cada individuo a la propia seguridad. En particular, la seguridad individual no queda explícitamente comprendida entre los derechos inviolables del hombre evocados por el art. $2 \mathrm{CPR}^{31}{ }^{31}$ Sin embargo debe considerarse que, según una tesis extendida en doctrina, los derechos inviolables no constituyen una categoría "cerrada", limitada al catálogo de derechos específicamente tutelados por la Constitución; se considera más bien que constituyen una categoría abierta, en la que pueden hacerse "entrar" algunos nuevos derechos emergentes en la conciencia social. En cualquier caso, sin entrar aquí en el debate italiano entre concepción abierta o cerrada del catálogo de derechos inviolables, parece aceptable la tesis según la cual con frecuencia los nuevos derechos emergentes en la

\footnotetext{
${ }^{29}$ Cfr. supra, par. 2 y 3.

${ }^{30}$ Sobre la seguridad como derecho fundamental de los individuos y deber del Estado cfr., de reciente, DONINI, Massimo, "Sicurezza e diritto penale", Cassazione penale, 2008, pp. 3559 y ss., con referencias bibliográficas adicionales.

${ }^{31}$ Cfr., para aclaraciones ulteriores cfr. RAIMONDI, Salvatore, "Per l'affermazione della sicurezza pubblica come diritto", cit. nota ${ }^{\circ} 21$, pp. 754-755.
} 
Constitución no son otra cosa más que aspectos particulares de los más tradicionales derechos expresamente previstos en el ámbito constitucional o, si se prefiere, derechos instrumentales respecto a éstos últimos, en cuanto funcionales para su tutela efectiva. ${ }^{32}$

En esta última perspectiva el derecho a la seguridad individual no sería otra cosa más que un derecho instrumental al efectivo goce de otros derechos de indudable cuño constitucional, como la vida, ${ }^{33}$ la salud, ${ }^{34}$ la propiedad, ${ }^{35}$ o la libre iniciativa económica. ${ }^{36}$

Con todo, es también cierto que la seguridad individual tiende siempre a superar su dimensión de derecho implícito e instrumental, para asumir un rol de derecho fundamental de carácter explícito y final; para asumir en consecuencia el rol de derecho merecedor - per sé - de tutela. En esta connotación la seguridad aparece, en particular, en el art. $2^{\circ}$ de la Declaración universal de los derecho humanos de 1948; y aparece asimismo, por lo que se refiere a las fuentes europeas, en el art. $5^{\circ} \mathrm{CEDU}$, el que se abre con la afirmación conforme a la que "toda persona tiene derecho a la libertad y a la seguridad"; así como en el art. $6^{\circ}$ de la Carta de derechos fundamentales UE de 2000, conforme al cual "todo individuo tiene derecho a la libertad y a la seguridad".

\section{La seguridad como derecho a la protección de intromisiones de los poderes públicos y su función antagonista respecto a los efectos liberticidas de la "seguridad pública".}

Queda todavía por explicar por qué el derecho a la seguridad personal podría obstaculizar la erosión de los derechos fundamentales consentida en cambio por la finalidad de seguridad pública. A primera vista se podría de hecho considerar que la seguridad personal debe ser entendida como "seguridad contra la criminalidad"; una seguridad frecuentemente perseguida por el legislador mediante el recurso a leyes penales y procesal penales de carácter marcadamente represivo, concebidas precisamente para asegurar una eficaz protección de los individuos y de la colectividad de cara a la criminalidad, incluso a costa de la limitación de algunos derechos y libertades fundamentales. Entonces, incluso en su acepción de derecho subjetivo, la seguridad podría terminar ya no por contraponerse, sino por favorecer la erosión de los derechos fundamentales con los que se encuentre en situación de "contra-balance".

Ahora bien, como veremos mejor dentro de poco, no se puede realmente excluir que el derecho a la seguridad sea entendido también como un derecho individual a ser tutelado frente a la criminalidad. Pero es igualmente indudable que no es aquél el único significado de tal derecho. En particular, no es por cierto éste el significado asumido para el derecho en

\footnotetext{
${ }^{32}$ Cfr., en particular y por todos, MODUGNO, Franco, I “nuovi diritti” nella giurisprudenza costituzionale I "nuovi diritti” nella giurisprudenza costituzionale, Turín: 1995, pp. 8 y ss.

${ }^{33}$ Pese a no tratarse de un derecho previsto explícitamente por ninguna norma específica, el reconocimiento a nivel contitucional del derecho a la vida puede fácilmente obtenerse a partir de un conjunto de normas constitucionales. Para una mención de dichas normas cfr., en particular, RAIMONDI, "Per l'affermazione della sicurezza pubblica come diritto", cit. nota ${ }^{\circ} 21$, p. 756.

${ }^{34}$ Cfr. art. 32 Const.

${ }^{35}$ Cfr. art. 42 Const.

${ }^{36}$ Cfr. art. 42 Const.
} 
Polit. crim. Vol. 5, No 9 (Julio 2010), Art. 2, pp. 68-113.

[http://www.politicacriminal.cl/Vol_05/n_09/Vol5N9A2.pdf]

cuestión en el art. 5 CEDU y en el art. 6 de la Carta de los derechos fundamentales UE de 2000. Dado de hecho que "históricamente en Europa los derechos fundamentales se han afirmado como protección frente a la intromisión de los poderes públicos", ${ }^{37}$ en las referidas Cartas de derechos la seguridad privada es prioritariamente entendida - conforme a interpretación unánime - como derecho dirigido a proteger a los individuos no ya de los ataques de la criminalidad, sino de las "arbitrarias interferencias de la autoridad pública". 38

Tal concepto de seguridad privada aparece con particular claridad en el art. $5^{\circ} \mathrm{CEDU}$, allí donde la seguridad de los individuos, entendida como un todo unitario con su libertad, tiende precisamente a ser garantizada a través de una especificación taxativa de las hipótesis derogatorias consentidas por el Estado. En todo caso, vale la pena precisar que tales hipótesis derogatorias de la libertad/seguridad individual presentan, en la gran mayoría de los casos, naturaleza de tipo penal (aludiendo a hipótesis de privación de libertad decididas en sede jurisdiccional), lo que quiere decir que implican el recurso a medidas de prevención que deben sujetarse a un tempestivo control judicial; control a continuación del cual se prevé el derecho a una reparación en el caso que se acredite que la restricción del derecho de libertad/seguridad por parte de los poderes públicos se ha verificado en violación de las disposiciones contenidas en el mencionado art. 5 CEDU.

8. La seguridad como derecho a ser tutelados frente a los "riesgos criminales". Sus perspectivas $y$ posibles efectos a nivel constitucional $y$ europeo (la actual incertidumbre con respecto a la existencia de un derecho semejante y de sus efectos en el ámbito constitucional. La gran actualidad de tal concepto de seguridad).

El hecho de que tanto en Italia como en Europa el derecho a la seguridad individual sea entendido a nivel supra-legislativo como derecho a ser tutelado de los abusos de la autoridad no significa sin embargo que, en los mismo ámbitos, no pueda también subsistir un derecho a la seguridad privada concebido como derecho a ser protegido frente a la criminalidad.

\subsection{La seguridad individual en el sistema italiano.}

Por el contrario, en relación con el sistema italiano, no está en algún modo descartado que el derecho implícito e instrumental a la seguridad, identificable en sede constitucional, pueda ser entendido (también) como expresión de la exigencia de tutela de cara a la criminalidad. Es verdad eso si que no es para nada fácil percibir los posibles desarrollos de un derecho semejante en el campo penal; ello también porque, hasta ahora, en Italia resulta arduo reconocer la existencia de "obligaciones constitucionales de incriminación"; es decir,

\footnotetext{
${ }^{37}$ RAIMONDI, Salvatore, "Per l'affermazione della sicurezza pubblica come diritto", cit. nota n 21, p. 751 .

${ }^{38}$ Así, con referencia específica al art. $5^{\circ}$ CEDU, CHIAVARIO, Processo e garanzie della persona, Milán, 1984, p. 315; PISANI, Mario, "Art. 5 - Diritto alla libertà e alla sicurezza", en BARTOLE, Sergio, CONFORTI, Benedetto, RAIMONDI; Guido, (dir.), Commentario della Convenzione europea dei diritti dell'uomo, Padua: 2001, p. 117. Con referenzia específica al art. $6^{\circ}$ de la Carta europea de los derechos fundamentales cfr. ANGELINI, Francesca, Ordine pubblico e integrazione costituzionale europea, cit. nota $\mathrm{n}^{\circ} 14$, pp. 14 y ss.
} 
el deber de carga del legislador de prever como delito - siempre y en todo caso - algunos hechos lesivos de bienes jurídicos de importancia primaria. ${ }^{39}$ En definitiva entonces, por una parte no es seguro que a nivel constitucional subsista un derecho a la seguridad individual de cara a la criminalidad y, por la otra, las repercusiones prácticas de un semejante derecho eventual son todo menos que pacíficas. ${ }^{40}$

En lo sucesivo tendré la ocasión de poner en evidencia cómo, más allá de las incertidumbres existentes a nivel constitucional, el problema del derecho a la seguridad frente a la criminalidad se esté convirtiendo en uno de los principales argumentos de la política criminal italiana. Lo anterior a causa de la creciente tendencia del poder político en orden a buscar el consenso popular promulgando leyes declaradamente concebidas para tutelar a los ciudadanos frente a la criminalidad.

\subsection{Las alusiones a la seguridad (personal) como "seguridad respecto a la criminalidad" se vuelven más precisas en el sistema de fuentes europeas.}

En efecto, ya en el preámbulo del Tratado $\mathrm{UE}^{41}$ se afirma la voluntad de "favorecer la libre circulación de las personas, garantizando al mismo tiempo la seguridad de sus pueblos, con la institución de un espacio de libertad, seguridad y justicia"; donde se comprende muy bien que tal forma de seguridad - entendida como un derecho tanto colectivo como individual - no quiere ser asegurado tanto - o, en todo caso, no sólo - de cara a las instituciones, como - o, en todo caso, también - de cara a la criminalidad. ${ }^{42}$

Por lo que se refiere al ya recordado art. 11 del Tratado UE, al afirmar éste que la política de seguridad busca tanto el "reforzamiento de la seguridad de la Unión en todas sus formas" como el "respeto de los derechos del hombre y de las libertades fundamentales", parece aludir a un concepto de seguridad entendido también como derecho fundamental (tanto del pueblo europeo como de sus miembros individualmente considerados) frente a toda forma de agresión, siendo la de origen criminal la primera de todas estas formas.

Si luego existieran aún dudas con respecto a que en sede de Tratado UE la seguridad debe ser entendida también como un derecho subjetivo a ser preservados frente a las insidias criminales, estas dudas serían definitivamente canceladas a partir de la lectura del art. 29 del Tratado, ${ }^{43}$ conforme al cual "el objetivo que la Unión se traza es el de ofrecer al ciudadano un nivel elevado de seguridad en un espacio de libertad, seguridad y justicia, desarrollando entre los Estados miembros una acción común en el sector de la cooperación policial y judicial en materia penal". Ofrecer seguridad a través de la cooperación de

\footnotetext{
${ }^{39}$ Sobre las obligaciones de incriminación cfr., por todos y limitatamente a la doctrina italiana, DOLCINI, Emilio, MARINUCCI, Giorgio, "Costituzione e politica dei beni giuridici”, Riv. it. dir. proc. pen., 1994, pp. 333 y ss.; PULITANò, Domenico, “Obblighi costituzionali di. tutela penale?”, Riv. it. dir. proc. pen., 1983, pp. 484 y ss.

${ }^{40}$ Al respecto cfr., por todos y de reciente, DI GIOVINE, Ombretta, "Il sindacato di ragionevolezza della Corte costituzionale in un caso facile", Riv. it. dir. proc. pen., 2007, pp. 100 y ss.

${ }^{41}$ Así modificado por el art. $1^{\circ}$, par. 3 del Tratado de Amsterdam de 1997.

${ }^{42}$ Cfr. Consejo de la Unión Europea, 14667/08 (prensa 299), versión provisoria, Comunicado de prensa, sesión N. 2899 del Consejo de Justicia y Asuntos de Interior, Luxemburgo, 24 octubre 2008, pp. 11 ss.

${ }^{43}$ Modificado por el art. $1^{\circ}$, par. 11 del Tratado de Amsterdam de 1997.
} 
Polit. crim. Vol. 5, No 9 (Julio 2010), Art. 2, pp. 68-113.

[http://www.politicacriminal.cl/Vol_05/n_09/Vol5N9A2.pdf]

órganos encaminados a prevenir y reprimir los delitos significa, en realidad, concebir la seguridad como un derecho a que la criminalidad, entre otras favorecida en sus actividades ilegales por la caída de las fronteras, sea eficazmente combatida a través de la acción coordinada de las fuerzas de policía y de la magistratura.

El concepto de "seguridad" como derecho de defensa de los sujetos frente a la criminalidad se encuentra incluso en la Carta de los derechos fundamentales UE del 2000, en cuyo art. 6 - como ha ya sido dicho - ha sido introducido el derecho a la seguridad con referencia a la ingerencia de los poderes públicos. En el preámbulo de esta Carta, de hecho, se afirma (par. 2) que "la Unión (...) coloca a la persona en el centro de su acción (...) creando un espacio de libertad, seguridad y justicia".

Pues bien, aunque pueda por cierto coinsiderarse todavía válida la afirmación según la cual "no es cierto que las finalidades políticas y sociales de este espacio hayan sido aún plenamente exploradas", 44 la frase antes citada del Preámbulo confirma nuevamente lo que es ya desde hace tiempo conocido universalmente: es decir, que con la creación y el desarrollo a partir de 1992 del "Espacio" en cuestión, la Unión europea ha querido buscar no sólo finalidades de seguridad común (interior y exterior), sino también finalidades de reforzamiento de los derechos de las personas que se encuentran y operan en tal espacio. Naturalmente, este reforzamiento se efectúa tutelando la seguridad de los ciudadanos UE frente a las instituciones: por ejemplo, recurriendo a jueces imparciales especialmente predispuestos $\mathrm{y}$ de procedimientos uniformes para hacer valer sus razones; o bien, asegurando - especialmente haciendo recurso a la amenaza penal - la protección de los datos personales, conforme a lo previsto en el art. 8 de la Carta de derechos fundamentales UE del 2000; pero también el reforzamiento en cuestión se efectúa garantizado a tales sujetos el derecho a la seguridad (individual, además de colectiva) respecto a las varias formas de criminalidad, ${ }^{45}$ especialmente de tipo transnacional.

Las razones que inducen a la Unión europea a activarse con todos los medios para oponerse a la criminalidad, se hallan muy bien resumidas en el portal-web de la Unión: "los ciudadanos europeos son hoy libres para viajar, trabajar y vivir en cualquier parte de la UE. Para poder gozar plenamente de esta posibilidad sin precedentes ellos deben sin embargo estar seguros de poderse mover y de atender a sus ocupaciones en toda seguridad. Deben ser protegidos frente a la criminalidad internacional y del terrorismo y, al mismo tiempo, reconocerse garantizado el derecho de acceder a la justicia en condiciones de paridad y el respeto de sus derechos fundamentales en toda la Unión”. Y aún: "garantizar la seguridad de los ciudadanos es una de las prioridades absolutas de la Unión. Ello significa servirse de

\footnotetext{
${ }^{44}$ LABAYLE, Henri, “L'espace pénal européen: instrument ou objectif?”, en: VAN DE KERCHOVE, Michel \& WEYEMBERGH, Anne, (coord.), Sécurité et justice : enjeu de la politique extérieure de l'Union européenne, Bruselas: 2003, p. 15.

${ }^{45}$ Cfr., por todos y con referencia especial al "espacio de libertad, seguridad y justicia" de la Unión Europea, PISANI, "Art. 5 - Diritto alla libertà e alla sicurezza", en: BARTOLE, Sergio, CONFORTI, Benedetto, RAIMONDI; Guido, (dir.), Commentario della Convenzione europea dei diritti dell'uomo, cit. nota $\mathrm{n}^{\circ} 38$, p. 118.
} 
instrumentos prácticos y jurídicos para impedir que las organizaciones criminales (...) saquen provecho de las libertades garantizadas por la UE." ${ }^{46}$

\section{La seguridad frente a la criminalidad, como objeto de la política criminal italiana y europea.}

Como se ha dicho, en Italia la constitucionalización del derecho a la seguridad frente a la criminalidad es todo menos que segura; igualmente, todo menos que seguros son los efectos que una constitucionalización semejante produciría en el plano penal.

Cierto es en cambio el progresivo crecimiento de la exigencia al legislador de seguridad, proveniente de los particulares y de la colectividad entera. ${ }^{47}$ Este crecimiento se debe, con toda probabilidad, a múltiples causas, entre las cuales merecen ser mencionadas en particular: el aumento - en términos estadísticos - de muchas formas, graves y menos graves, de criminalidad; la mayor percepción del riesgo criminal, especialmente a causa del espacio reservado a la crónica negra en los medios de información; la multiplicación de los factores de peligro al interior de la sociedad moderna, no por casualidad denominada, precisamente, "del riesgo"; 48 la pérdida, en la sociedad del bienestar, de una aproximación a la vida de tipo fatalista, también por lo que concierne a la menor aceptación del posible rol de la propia víctima.

$\mathrm{Si}$ entonces todos estos factores confluyen de manera de incrementar una exigencia generalizada de seguridad, ${ }^{49}$ resulta por otra parte cierto que de parte de la opinión pública las exigencias más perentorias en tal sentido guardan relación sólo con los delitos mayormente idóneos para suscitar alarma social; lo anterior incluso si, como veremos, parece legítimo considerar que el poder político y el poder mediático puedan contribuir de manera potente a dirigir la alarma social hacia tipologías criminales bien precisas.

Pues bien, allí donde - de modo espontáneo o dirigido - la exigencia colectiva de seguridad respecto a ciertas formas de criminalidad se vuelve impelente, tanto en Italia como en cualquier otro país democrático, las fuerzas políticas que se hallan en el poder tienen todo el interés en dar respuestas al menos aparentemente satisfactorias a esta exigencia, de manera de aumentar el consenso social en torno a si mismas. Naturalmente, también las fuerzas políticas que se hallan en la oposición tienen todo el interés en "cabalgar" o aprovechar semejante exigencia de seguridad, sugiriendo reformas penales que, por lo demás, en el plano de los contenidos pueden en ocasiones apartarse en modo más o menos evidente de aquellas compartidas por la mayoría. Se afirma así una "política criminal de la seguridad" tendiente no sólo a oponerse por vía privilegiada a tipologías particulares de

\footnotetext{
${ }^{46}$ Así, Giustizia, libertà e sicurezza. Per sostenere $i$ nostri diritti e difendere $i$ nostri interessi, en http://europa.eu/pol/justice/overview it.htm

${ }^{47}$ Cfr., por ejemplo, PADOIN, Paolo, "La sicurezza nelle città: città inclusiva, città sicura", Nuova rassegna di legislazione, dottrina e giurisprudenza, 2006, pp. 251 y ss.

${ }^{48}$ Con respecto a la cual cfr., fundamentalmente, BECK, Ulrich, La società del rischio, Roma: 2000. En particular, es indudable con el progreso de la ciencia y de la técnica se ha incrementado la exposición a riesgos de naturaleza culposa.

${ }^{49}$ Cfr., de reciente y por todos, DONINI, Massimo, Sicurezza e diritto penale, cit. nota $n^{\circ} 30$, en particular, pp. 3561 y ss.
} 
Polit. crim. Vol. 5, No 9 (Julio 2010), Art. 2, pp. 68-113.

[http://www.politicacriminal.cl/Vol_05/n_09/Vol5N9A2.pdf]

delitos, sino también a perseguir la "prevención general integradora"; es decir, a perseguir aquella forma de prevención encaminada a la estabilización social a través del recurso a medidas penales capaces de catalizar el consenso de la mayoría de los ciudadanos. ${ }^{50}$

Llegados a este punto corresponde subrayar que, desde hace algunas décadas, en Europa las exigencias de política criminal no se limitan a la sola competencia de los Estados. De hecho, conforme a la voluntad de un número creciente de países europeos en orden a perseguir una integración progresiva, en algunos sectores de la política criminal un rol cada vez más importante es ahora atribuido a dos organizaciones internacionales de carácter regional. Se alude al Consejo de Europa y, sobre todo, a la Unión Europea.

Por lo que se refiere al Consejo de Europa, éste surgió después de la Segunda Guerra mundial como respuesta a la necesidad de reforzar los vínculos entre los países del viejo continente, con el fin de evitar la repetición de conflictos causados ante todo por la intolerancia recíproca y por la contraposición de los Estados. Nacido también - y sobre todo - bajo la onda generada por los impulsos ideales compartidos por quienes se habían opuesto al fascismo y al nazismo, el Consejo de Europa tiene como primer objetivo el de "conseguir una más estrecha unión entre sus miembros, ${ }^{51}$ para salvaguardar y promover los ideales y los principios que constituyen su patrimonio común y de favorecer su progreso económico y social"; objetivo éste que debe ser perseguido "con acuerdos y mediante una acción común en los campos económico, social, cultural, científico, jurídico y administrativo (...)" ${ }^{52}$ Pues bien, muchos de estos acuerdos - los que asumen la forma de convenciones internacionales capaces de vincular a los Estados miembros sólo con posterioridad a su ratificación - apuntan precisamente, como veremos mejor a continuación, a oponerse a algunas formas particularmente temibles de criminalidad. ${ }^{53} \mathrm{De}$ este modo el Consejo de Europa concurre a fin de elevar el nivel de seguridad en el ámbito europeo, acercando y haciendo compatibles las normativas penales internas de sector, tanto penales como procesal penales.

Por lo que se refiere a la Unión Europea (UE), ella fue creada en 1992 a modo de desarrollo de la Comunidad Europea (CE) surgida en los años '50 del siglo pasado. La UE no es una simple organización intergubernamental, pero tampoco una federación de Estados; es más bien un organismo sui generis, a cuyas instituciones los Estados miembros ${ }^{54}$ han cedido sectores de la propia soberanía nacional. Las competencias de la UE incluyen las relaciones exteriores, la defensa, las políticas económicas, la agricultura, el comercio y la protección ambiental.

\footnotetext{
${ }^{50}$ Cfr., críticamente y por todos, PAVARINI, Massimo, "Il "grottesco" della penologia contemporanea", en: CURI, Umberto, \& PALOMBARINI, Giovanni, (coord.), Diritto penale minimo, Roma: 2002, p. 282. De reciente, los riesgos de adoctrinamiento asociados a tal forma de prevención general aparecen bien destacados por PALAZZO, Francesco, Corso di diritto penale. Parte generale, Turín: 2008, pp. 18 y ss., p. 38.

${ }^{51}$ Que actualmente son 47.

${ }^{52}$ Cfr. art. $1^{\circ}$ del Estatuto del Consejo de Europa, firmado en Londres el 5 de mayo de 1949 y en vigor desde el 3 de agosto del mismo año.

${ }^{53}$ A este respecto, resulta inequívoca la lectura de la lista completa de los tratados del Consejo de Europa, en http://conventions.coe.int/Treaty/Commun/ListeTraites.asp?CM=8\&CL=ENG

${ }^{54}$ Que actualmente son 27.
} 


\section{BERNARDI, ALESSANDRO. "Seguridad y Derecho Penal en Italia y en la Unión Europea".}

La UE se articula en tres pilares distintos, ${ }^{55}$ cada uno de los cuales es depositario de competencias específicas. En particular, por aquello que aquí nos interesa, el tercer pilar mira a construir un espacio europeo de libertad, seguridad y justicia, idóneo para una mejor oposición a la criminalidad transnacional. Para tal fin, los instrumentos jurídicos UE generados en el ámbito del tercer pilar, estimulan o bien, derechamente, obligan ${ }^{56}$ a los Estados miembros a emprender múltiples formas de colaboración administrativa y judicial, además de intensos procesos de armonización normativa en el ámbito del derecho y del procedimiento penal. ${ }^{57}$

En definitiva, por tanto, en Europa la política criminal no es una prerrogativa exclusiva de los Estados, en la medida que también el Consejo de Europa y la Unión Europea desarrollan líneas propias de política criminal a través del recurso a instrumentos jurídicos ad hoc, cuya eficacia está de todas formas condicionada por la voluntad de los países miembros. En cualquier caso, tanto las políticas criminales nacionales como aquellas europeas, se hallan significativamente influenciadas por el argumento de la seguridad colectiva e individual.

\section{La política criminal italiana en materia de seguridad. En particular, la lucha "selectiva" contra las formas de macro-criminalidad.}

Como ha sido mencionado anteriormente, el tema de la seguridad tiende cada vez más a condicionar el debate parlamentario y las decisiones político-criminales en Italia. En realidad, no se trata de un fenómeno nuevo, en cuanto nuestra "democracia de opinión" se demuestra desde hace tiempo particularmente sensible a las expectativas y emociones de los ciudadanos. En particular, a partir de los años '70 del siglo pasado, algunos fenómenos criminales han asumido dimensiones tales, como para generar gran alarma social y para activar una "demanda de seguridad" cada vez más apremiante. Se alude, por una parte, a la prepotente aparición en nuestro país de formas de criminalidad organizada, ya nuevas, ya

\footnotetext{
${ }^{55}$ Caracterizados, además, por diferentes mecanismos de generación de las respectivas normas. En extrema síntesis, el primer pilar atañe a la Comunidad Europea (CE), es decir, en particolar, el establecimiento de un mercado común europeo y de una unión económica-monetaria; el segundo pilar concierne a la política de exterior y de seguridad común PESC), es decir, la construcción de una política única hacia el exterior; el tercer pilar - come será precisado de mejor manera en lo sucesivo de esta conferencia — tiene por objeto la cooperación y la armonización en materia penal. Nota del autor: es importante destacar que tras la elaboración final del presente escrito-conferencia, se completó la ratificación del Tratado de Lisboa por parte de los 27 Estados membro de la Unión. Tal tratado, entrado en vigencia el 1 de diciembre de 2009, modificó profundamente la configuración institucional de la Unión Europea; en particular, poniendo fin al sistema de los tres pilares y generalizando el "método comunitario", anteriormente previsto sólo para el primero de tales pilares.

${ }^{56}$ Conforme al art. 34 letra $b$ ) del Tratado UE, los actos normativos más frecuentemente utilizados en el ámbito del tercer pilar (es decir, las denominadas "decisiones marco") "son vinculantes para los Estados miembros en cuanto al resultado a obtener, quedando la forma y los medios entregados a la competencia de las autoridades nacionales (...)".

57 Cfr. BERNARDI, Alessandro, "Politiche di armonizzazione e sistema sanzionatorio penale", en: RAFARACI, Tommaso (coord.), L'area di libertà, sicurezza e giustizia. Alla ricerca di un equilibrio tra priorità di sicurezza ed esigenze di garanzia, Milán: 2007, pp. 266 y ss.; ID., "Il ruolo del terzo pilastro UE nella europeizzazione del diritto penale. Un sintetico bilancio alla vigilia della riforma dei Trattati”, Rivista italiana di diritto pubblico comunitario, 2007, pp. 1166 y ss.
} 
Polit. crim. Vol. 5, No 9 (Julio 2010), Art. 2, pp. 68-113.

[http://www.politicacriminal.cl/Vol_05/n_09/Vol5N9A2.pdf]

existentes desde antes al interior de la sociedad; y, por la otra, al crecimiento exponencial de la denominada "criminalidad callejera" en sus diversas manifestaciones.

\subsection{Respecto del terrorismo.}

Por lo que atañe específicamente a la criminalidad organizada, es precisamente en el inicio de los años '70 que en Italia se afianza el fenómeno del terrorismo en dos versiones distintas: el terrorismo negro de derivación fascista, y el rojo de derivación comunista. Aun si distintos no sólo en lo relativo a la matriz política, sino también por lo que se refiere a las formas de manifestación, ${ }^{58}$ ambas variantes de terrorismo concluían con el atentado de la seguridad, tanto del Estado y de sus instituciones, como de la colectividad y de los ciudadanos individualmente considerados.

\subsection{Respecto de la criminalidad organizada.}

En el plano de la seguridad, no resultan distintos los perjuicios causados por la criminalidad organizada de tipo mafioso, dirigida a constituir un verdadero y propio contra-poder ilegal en el interior del Estado. Esta forma de criminalidad, desde hace mucho tiempo existente en nuestro país, se ha indudablemente reforzada a partir de los años ' 70 , aprovechando también del empeño preferente del Estado en el frente del terrorismo. De esta forma fue progresivamente apareciendo al descubierto, reivindicando espacios de acción cada vez más extensos, gracias además al recurso a toda forma de intimidación, al homicidio de jueces y de políticos, así como a los atentados de gran escala.

Ahora bien, la alarma social provocada por las dos formas de criminalidad organizada recién mencionadas y de los delitos cada vez más resonantes a ellas atribuibles, ha favorecido la adopción de reformas legislativas de carácter marcadamente preventivorepresivo, por cierto no carentes de eficacia. En efecto, han sido satisfactorios los resultados obtenidos por tales reformas en la lucha contra el terrorismo nacional y - aunque sólo en parte -contra la mafia. Lástima que, para perseguir finalidades de seguridad colectiva e individual, las aludidas reformas hayan terminado también comprimiendo significativamente algunos derechos y garantías fundamentales, determinando un proceso de progresiva barbarización del derecho punitivo; ${ }^{59}$ barbarización considerada, por la mayoría, una suerte de "mal menor" o de "mal necesario" 60 con miras al "bien supremo" de

\footnotetext{
${ }^{58}$ Mientras que, para aumentar la "tensión social" y crear el terreno propicio para un "golpe de Estado", el terrorismo negro opta por los asesinatos de ciudadanos comunes, así como al posterior despiste respecto a los autores del hecho, el terrorismo rojo privilegia el secuestro y el homicidio de sujetos señalados como "enemigos del pueblo", para estimular la rebelión del proletariado y la llegada del "socialismo real".

59 Cfr., por ejemplo, MAGISTRATURA DEMOCRATICA, "Situazione carceraria e repressione penale", Critica del diritto, 1982, pp. 45 y ss.; cfr. asimismo las observaciones de INSOLERA, Gaetano, "Ordine pubblico e ordine democratico: le stagioni dell'emergenza", Critica del diritto, gennaio-marzo 2003, pp. 19 y ss.

${ }^{60}$ Cfr., por todos, VIGANÒ, Francesco, "Terrorismo, guerra e sistema penale", Riv. it. dir. proc. pen., 2006, p. 696. El autor destaca que en sede de "balance entre seguridad-prevención y tutela de los derechos individuales, el primer punto de vista aparece casi siempre en posición de ventaja ante la opinión pública y las fuerzas políticas, porque promete éxitos rápidos (...); mientras que es siempre más difícil para el jurista mostrar las consecuencias negativas de las limitaciones a los derechos individuales, las que al momento de la decisión tienden a aparecer abstractas y de largo plazo".
} 


\section{BERNARDI, ALESSANDRO. "Seguridad y Derecho Penal en Italia y en la Unión Europea".}

la seguridad. Basta pensar en las muy discutidas medidas de prevención ante delictum utilizadas contra los indagados por pertenencia a la mafia o por actividad terrorista; ${ }^{61}$ en el robusto uso de la prisión preventiva y en el rol vicario por ella asumido respecto a la pena, en el caso de imputados por terrorismo y pertenencia a asociación mafiosa; ${ }^{62}$ en las cuestionables normas en materia de asociaciones mafiosas y en los igualmente cuestionables tipos caracterizados por la "finalidad de terrorismo y de eversión del orden democrático"; 63 en el endurecimiento del tratamiento penitenciario contra los mafiosos irreductibles; ${ }^{64}$ en la controvertida regulación "premial" prevista a favor de terroristas y mafiosos "arrepentidos" [los "pentiti", ndt.]; ${ }^{65}$ en suma, en todas aquellas normas de la legislación de emergencia que, desde diversos puntos de vista, estaban o están todavía hoy al límite de la legitimidad constitucional. ${ }^{66}$

\subsection{Respecto de otras formas de criminalidad organizada.}

Pero en Italia las formas de criminalidad organizada idóneas para comprometer la seguridad colectiva e individual no se reducen por cierto al terrorismo y a la mafia (en sus diversas acepciones: ndrangheta calabresa, camorra de la Campania, sacra corona unita apuliana, etc.). En realidad, otras formas de criminalidad organizada se han ido constituyendo en el transcurso del tiempo, manteniendo a veces una cierta independencia respecto a las asociaciones de tipo mafioso: basta pensar en las organizaciones criminales especializadas en el tráfico de drogas y/o de armas, o bien a aquellas dedicadas al comercio clandestino, o incluso aun a aquellas destinadas a la explotación de la prostitución, a las extorsiones, a los secuestros de persona, a la pedofilia, al comercio ilegal de órganos para transplantes, a la distribución y suministro de sustancias para doping o de fármacos en mal estado o vencidos.

\footnotetext{
${ }^{61}$ Cfr. dentro de una bibliografía muy extensa, BRICOLA, Franco, “Forme di tutela 'ante delictum' e profili costituzionali della prevenzione", en: AA.VV., Le misure di prevenzione, Milán: 1975, pp. 68 y ss.; VASSALLI, Giuliano, "Misure di prevenzione e diritto penale", en: AA.VV., Studi in onore di B. Petrocelli, III, Milán: 1972, pp. 1628 y ss. Con la complicidad de la fuerte alarma social suscitada por los recientísimos e impresionantes atentados terroristas de matriz internacional, se asiste últimamente al uso bastante desenvuelto de la medida preventiva de expulsión contra los extranjeros sospechosos de ser cercanos a los ambientes terroristas en cuestión, hasta el punto de despertar la sospecha de que las garantías del procedimiento de expulsión (con respecto a las cuales cfr., en particular, NASCIMBENE, "Le garanzie nel procedimento di espulsione dello straniero", en: SALERNO, Francesco, (coord.), Diritti dell'uomo, estradizione ed espulsione, Padua: 2003, pp. 183 y ss.) no se estén respetando siempre, plenamente.

${ }^{62}$ Cfr., en particular, MOCCIA, Sergio, La perenne emergenza. Tendenze autoritarie nel sistema penale, Nápoles: 1995, pp. 152 y ss., con referencias bibliográficas ulteriores.

${ }^{63}$ Cfr., en particular, MOSCARINI, Paolo, "In tema di reati commessi per finalità di terrorismo o d' eversione", Giur. it., 1982, pp. 471 y ss.; CENCI, Piero, "Aggravante della finalità del terrorismo o di eversione dell' ordine democratico", Giur. merito, 1983, pp. 485 y ss.

${ }^{64}$ Cfr., por todos, GIUNTA, Fausto, "L. 16 febbraio 1995, n. 36 - Proroga delle disposizioni di cui all'art. 41 bis 1. 26 luglio 1975, n. 354, sulla sospensione delle normali regole di trattamento penitenziario", $L a$ legislazione penale, 1996, pp. 45 y ss.; RUOTOLO, Marco, "Quando l'emergenza diventa quotidiana. Commento alle modifiche agli artt. 4-bis e 41-bis dell'ordinamento penitenziario", Studium iuris, 2003, pp. 417 y ss.

${ }^{65}$ Cfr., fundamentalmente, PADOVANI, Tullio, "La soave inquisizione. Osservazioni e rilievi a proposito delle nuove ipotesi di "ravvedimento"', Riv. it. dir. proc. pen., 1981, pp. 529 y ss.

${ }^{66}$ Cfr., por todos, PALAZZO, Francesco, La recente legislazione penale, Padua: 1980, pp. 95 y ss.
} 
Polit. crim. Vol. 5, No 9 (Julio 2010), Art. 2, pp. 68-113.

[http://www.politicacriminal.cl/Vol_05/n_09/Vol5N9A2.pdf]

Ahora bien, como ya ha acontecido a propósito de la criminalidad terrorista y mafiosa, en Italia cada una de estas ulteriores formas de criminalidad organizada ha determinado decisiones normativas y/o prácticas que, si bien adoptadas por evidentes razones de seguridad, aparecen no obstante en tensión con los principios informadores de todo sistema penal democrático y garantista.

De esta forma hemos podido presenciar el frecuente recurso a normas carentes de claridad y precisión en materia de asociaciones criminales, ${ }^{67}$ así como a normas caracterizadas por una más o menos evidente oposición al principio de lesividad u ofensividad (tipos penales de atentado, de peligro abstracto, formales o de pura desobediencia, dirigidas a atacar la mera personalidad del autor o su estilo de vida). ${ }^{68}$ Por lo que luego concierne a las sanciones, no sin frecuencia se han adoptado decisiones punitivas excesivamente severas en relación a algunos de los fenómenos criminales antes considerados, hasta despertar la sospecha de que el propio principio de proporcionalidad de la pena resulte vulnerado. También en estos casos entonces, en nombre de la primacía de la "seguridad frente a la criminalidad", se ha terminado por sacrificar algunos principios garantistas expresivos - si no del derecho - al menos del interés del individuo en hallarse al reparo de las ingerencias del Estado.

En todo caso, en Italia existen vistosas excepciones a la hasta aquí mencionada aproximación de lucha a ultranza conducida por el legislador - en nombre de la seguridad frente a las diversas formas de criminalidad organizada. Se hace esencialmente referencia ahora a las formas de criminalidad organizada en los sectores de la economía y de la política; sectores éstos que muy a menudo se entrecruzan, dando vida a fenómenos de trasfondo fraudulento y corrupto, y que contaminan gravemente el mundo de los negocios y el desarrollo de las funciones públicas. Se piense a las actividades dirigidas tanto a falsificar los balances de las empresas - incluso para crear fondos negros destinados a condicionar ilícitamente la vida política -, como ha interferir en el buen funcionamiento de la competencia y de las licitaciones públicas, así como, en definitiva, a empobrecer a la colectividad y a sujetos individuales en provecho de un estrecho círculo de personas corruptas y que se hallan en posiciones apicales. Pues bien, considerado que en Italia las mencionadas actividades se incrementaron fuertemente en el curso de los años ' 70 y sobre todo en los '80, minando así la seguridad de los ahorrantes y la credibilidad de las instituciones democráticas, al inicio de los años '90 los jueces se empeñaron a fondo en una actividad de oposición a la criminalidad económica y política, hasta decretar - de hecho el fin de algunos partidos políticos cuyos vértices habían resultado particularmente implicados en las actividades de corrupción.

Sin embargo, las fuerzas políticas que se han sucedido en el gobierno en los últimos quince años, ciertamente no se han activado para impedir la reiteración de comportamientos ilegales similares, mediante la introducción de reformas específicas y eficaces, o bien mediante una acción de sostén de la actividad policial y judiciaria en los sectores de que se trata. Por el contrario, algunas de estas fuerzas políticas se han destacado particularmente

\footnotetext{
${ }^{67}$ Cfr., por todos, FERRAJOLI, Luigi, "Sul diritto penale minimo (risposta a Giorgio Marinucci e a Emilio Dolcini)", Foro it., 2000, V, c. 128-129.

${ }^{68}$ Como en el caso de la incriminación de la descarga vía internet de imágenes pedófilas virtuales.
} 
por proponer y promulgar reformas marcadas por una manifiesta indulgencia para con los mencionados sectores criminales, si ya no derechamente fundadas sustancialmente "en la pretensión de sustraer del control de legalidad a los niveles superiores de la actividad económico-financiera y político-administrativa". ${ }^{69}$ En este sentido resultan emblemáticas tanto la reciente reforma al derecho penal societario, que vino a despenalizar algunas hipótesis de falsedad en balances, incluso a costa de desatender en lo pertinente los vínculos normativos de fuente comunitaria-europea; ${ }^{70}$ así como la normativa sobre las cartas rogatorias internacionales, destinada de hecho a obstaculizar la recolección de las pruebas de presuntas colusiones ilícitas entre el mundo empresarial/político, el mundo forense y exponentes de la magistratura. ${ }^{71}$

Desde una arista diversa - no necesariamente relacionada a fenómenos de criminalidad organizada - también el recurso inflacionario al mecanismo de las condonaciones (por los ilícitos en materia fiscal, edilicia, etc.), si por una parte puede llevar un poco de dinero a las arcas del Estado, ${ }^{72}$ por otra parte termino por favorecer la cultura de la ilegalidad. Con ello se refuerza la idea según la cual violar la ley, al menos en determinados sectores, resulta a la larga ventajoso. Personalmente, concuerdo con quienes, en franca polémica con las actuales líneas de política criminal, aluden abiertamente a un "uso instrumental de instancias de carácter garantista", 73 con miras a perseguir una "malentendida idea de la concepción neo-liberal", ${ }^{74}$ si no ya derechamente destinado a asegurar una casi total inmunidad para los miembros de las clases hegemónicas. ${ }^{75}$ Para perseguir de mejor forma dichos objetivos, una vasta parte de las fuerzas políticas y de los órganos de información a ellas relacionados se movilizan para atenuar - respecto a estos sectores de la criminalidad - la alarma social y la "demanda de seguridad" que le sigue. El fin evidente es el de dirigir la demanda de seguridad hacia diversos y más tradicionales sectores de la criminalidad, de manera que sobre ellos se concentren los "recursos preventivo-represivos" del Estado. ${ }^{76}$

\footnotetext{
${ }^{69}$ PALOMBARINI, Giovanni, "Per un altro diritto penale", en Diritto penale minimo, cit. nota n ${ }^{\circ} 50$, p. 3.

${ }^{70}$ Cfr., en particular, BIN, Roberto, BRUNELLI Giuditta, PUGIOTTO, Andrea, VERONESI, Paolo, (coord.), Ai confini del “favor rei". Il falso in bilancio davanti alle Corti costituzionale e di giustizia, Turín, 2005.

${ }^{71}$ Cfr., en particular, BROGGINI,Gerardo, "Le rogatorie italo-svizzere alla luce della 1. 5 ottobre 2001, n. 367”, Riv. it. dir. proc. pen., 2002, pp. 116 y ss.; SAVARESE, Eduardo, "Cooperazione giudiziaria e garanzie processuali, con particolare riguardo all'utilizzabilità del materiale probatorio acquisito in esecuzione di commissioni rogatorie, alla luce della 1. 5 ottobre 2001, n. 367”, Giur. it., 2003, pp. 603 y ss.; SECCHI, Zaira, "Rogatorie con la Svizzera: risposta italiana alle attività transnazionali della criminalità (lucido disegno o confusione mentale?)", Questione giustizia, 2002, pp. 90 y ss.

72 De hecho, se trata de condonaciones concedidas previo pago de una suma de dinero, aun si en general muy modesta, especialmente en consideración a lols beneficios obtenidos mediante la realización de los ilícitos condonados.

${ }^{73}$ PALOMBARINI, Giovanni, "Per un altro diritto penale”, en Diritto penale minimo, cit. nota n 50 , p. 3.

${ }^{74}$ GROSSO, Carlo Federico, "Riserva di codice, diritto penale minimo, carcere come extrema ratio di tutela penale", en Diritto penale minimo, cit. nota $\mathrm{n}^{\circ} 50, \mathrm{p} .103$.

${ }^{75}$ Sobre el punto, cfr. emblemáticamente y por todos, COLOMBO, Gerardo, Tolleranza zero, introduzione a FENECH, en: FENECH, Georges, Tolleranza zero, Milán: 2001, pp.18 y ss.

${ }^{76}$ Cfr., al respecto, las ideas de PAVARINI, Massimo, "“Vecchia” e "Nuova " legalità", Critica del diritto, 2003, pp. 96 y ss.
} 
Polit. crim. Vol. 5, No 9 (Julio 2010), Art. 2, pp. 68-113.

[http://www.politicacriminal.cl/Vol_05/n_09/Vol5N9A2.pdf]

\section{La política judicial italiana a favor de la seguridad contra la "maxi-criminalidad". En particular, la dilatación de la responsabilidad de los líderes de la asociación criminal y la punibilidad por "concurso externo" de personas en tales asociaciones.}

En Italia, no sólo el legislador combate enérgicamente las formas de criminalidad organizada que, por su especial peligrosidad, suscitan alarma social y demandas de seguridad en la mayoría de los ciudadanos. También la magistratura hace a menudo uso de su poder discrecional para luchar contra tales asociaciones criminales y, más en general, contra quienes giran en torno a ellas.

Por lo demás, a esta altura es ya indudable que los jueces pueden interferir, a través de la denominada "política judicial", en las decisiones político criminales del legislador, atenuando o acentuando por vía interpretativa los efectos represivos de las específicas normas de incriminación, así como los efectos de algunas normas penales de parte general (por ejemplo, de las normas en materia de tentativa, concurso de personas, concurso de delitos, etc.).

Ahora bien, el rol de los jueces en sede de concretización de las normas penales, se vuelve particularmente importante en el ámbito de aquellos "tipos de asociación"77 introducidos por el legislador italiano con el fin de contrarrestar las actividades mafiosas ${ }^{78}$ y terroristas. ${ }^{79}$

\footnotetext{
${ }^{77}$ Es decir, de tipos penales que castigan como delito el hecho mismo de asociarse con el fin de cometer una pluralidad de delitos.

${ }^{78}$ Art. 416-bis. "Asociación de tipo mafioso".

"Todo aquél que forma parte de una asociación de tipo mafioso formada por tres o más personas, es castigado con reclusión de siete a doce años.

Quienes promueven, dirigen u organizan la asociación son castigados, sólo por ello, con reclusión de nueve a catorce años.

La asociación es de tipo mafioso cuando quienes la integran se valen de la fuerza de intimidación del vínculo asociativo y de las condiciones de sometimiento y de la "ley de silencio" que de aquel vínculo se deriva, para cometer delitos, para conquistar en modo directo o indirecto la gestión o bien el control de actividades económicas, de concesiones, de autorizaciones, licitaciones y servicios públicos, o para obtener ganancias o ventajas injustas para si o para otros, o bien con el fin de impedir u obstaculizar el libre ejercicio del voto o de procurar votos para si o para otros con ocasión de votaciones populares.

Si la asociación es armada, se aplica la pena de reclusión de nueve a quince años en los casos previstos en el inciso primero y de doce a veinticuatro años en los casos previstos en el inciso segundo.

La asociación se considerada armada cuando, para la consecución de la finalidad de la asociación, los participantes tienen la disponibilidad de armas o materias explosivas, aun si ocultas o mentenidas en un lugar de depósito.

Si las actividades económicas respecto de las cuales los asociados buscan asumir o mantener el control son financiadas en todo o en parte con el precio, producto o ganancia de delitos, las penas establecidas en los incisos precedentes se aumentan desde un tercio a la mitad.

Respecto al condenado es siempre obligatoria la confiscación de las cosas que sirvieron o fueron destinadas para cometer el delito, así como de las cosas que corresponden a su precio, producto, ganancia o que constituyen su uso.

Las disposiciones del presente artículo se aplican también a la camorra y a las demás asociaciones que, cualquiera sea su denominación local, incluidas las extranjeras, valiéndose de la fuerza intimidante del vínculo asociativo persiguen objetivos correspondientes a aquellos de las asociaciones de tipo mafioso.

79 Art. 270-bis. "Asociaciones con finalidad de terrorismo - incluso internacionales - o de subversión del orden democrático".
} 


\section{BERNARDI, ALESSANDRO. "Seguridad y Derecho Penal en Italia y en la Unión Europea".}

Considerando que para ser castigados por un delito de asociación basta el acuerdo criminal por parte de tres o más personas con miras a cometer delitos, y que la prueba de tal acuerdo, de carácter general y continuado, es entregada al juicio de los magistrados, bien se comprende el rol protagónico asumido por estos últimos en la valoración de la configuración del delito.

Todavía mayor resulta luego la discrecionalidad de los jueces en la valoración de las complejas situaciones que se dan en el ámbito de los delitos de asociación en materia de concurso de personas. En esta sede me limitaré a mencionar dos problemas emblemáticos. El primero se refiere al problema de la responsabilidad, a título de concurso de personas o participación, de los jefes de las asociaciones ilícitas, por los específicos delitos realizados por los miembros de la asociación; el segundo problema se refiere a la hipótesis denominada de "concurso externo" en el delito de asociación.

\subsection{El problema de la responsabilidad de los jefes de asociaciones ilícitas por los delitos específicos realizados por los miembros de la asociación.}

Por lo que concierne a la responsabilidad de los jefes de las asociaciones ilícitas respectos a los específicos delitos realizados por los miembros de la asociación, en los períodos en los que la amenaza a la seguridad por parte del terrorismo y la mafia ha sido más alta, la magistratura italiana no ha vacilado en dictar sentencias no sólo extremadamente severas, sino que incluso en los límites de la legalidad. Se ha terminado de hecho sancionando hipótesis de "responsabilidad de posición", con prescindencia de toda relación causal entre la conducta de los superiores y aquellas de los partícipes en los específicos delitos reconducibles al "programa criminal" de la asociación (los denominados "delitos-fin").

Así, por ejemplo, en los denominados "años de plomo" en los que el terrorismo italiano apuntaba a derribar las instituciones democráticas, a los líderes de las organizaciones terroristas les fueron en ocasiones atribuidos (automáticamente), a título de "concurso moral", los delitos (robos para financiar a la organización, secuestros, homicidios) cometidos por los miembros de la misma organización. Lo anterior, sobre la base del siguiente argumento: que tales delitos no podían no ser previstos y aceptados por los promotores y organizadores de la asociación, en cuanto desarrollos naturales del programa de la asociación. ${ }^{80}$ Es más, en virtud de los estrechísimos e ineludibles nexos entre actividad de organización de la asociación terrorista y actividad de realización del

\footnotetext{
"Todo aquél que promueve, constituye, organiza, dirige o financia asociaciones que se proponen la realización de actos de violencias con finalidades de terrorismo o de subversión del orden democrático, es castigado con reclusión de siete a quince años.

Todo aquél que participa en tales asociaciones es castigado con reclusión de cinco a diez años.

Para los efectos de la ley penal, la finalidad de terrorismo también concurre cuando los actos de violencia son dirigidos contra un Estado extranjero, una institución o un organismo internacional.

Respecto al condenado es siempre obligatoria la confiscación de las cosas que sirvieron o fueron destinadas para cometer el delito, así como de las cosas que corresponden a su precio, producto, ganancia o que constituyen su uso.

${ }^{80}$ Cfr., por todos, Corte di Assise de Milán, sent. 21 junio 1980; Corte di Assise de Roma, 24 enero 1983 , Foro it., 1984, II, c. 187 y ss., con nota de RAPISARDA, Carmelo; Corte di Assise de Turín, 26 de julio de 1983.
} 
Polit. crim. Vol. 5, No 9 (Julio 2010), Art. 2, pp. 68-113.

[http://www.politicacriminal.cl/Vol_05/n_09/Vol5N9A2.pdf]

respectivo programa, se consideró incluso que "el jefe de la asociación debería responder del delito cometido por el asociado, aun en el caso de un disenso explícito de su parte respecto al delito realizado". 81

Con respecto a los delitos de mafia, la jurisprudencia ha afirmado en más de una ocasión que los vértices de las asociaciones mafiosas han de ser considerados responsables a título de concurso de personas por los delitos cometidos por los asociados, en todos los casos en los que no prohíban expresamente su realización, amenazando con sanciones en caso de incumplimiento de la prohibición. Y aún más, en una perspectiva no muy diferente, se ha estimado que los miembros de los vértices de la organización han de ser considerados responsables allí donde no se ofrezca una concreta prueba de que ellos no habían de algún modo reforzado la voluntad de los asociados en relación a los delitos cometidos por estos últimos. ${ }^{82}$ Se comprende muy bien, de hecho, cuán difícil resulta excluir con certeza semejante efecto de reforzamiento de la voluntad de los asociados que se hallan en posición subalterna.

En todo caso, las orientaciones jurisprudenciales hasta aquí referidas son miradas con antipatía por la doctrina dominante, ${ }^{83}$ y aun - ahora - por la misma Corte de Casación. ${ }^{84}$ De hecho, tanto la una como la otra se orientan en el sentido de estimar que la responsabilidad penal de los líderes de las asociaciones criminales por los específicos delitos realizados por los miembros de las mismas, debe condicionarse a la prueba de una efectiva contribución causal por parte de los primeros con respecto a los delitos realizados por los segundos. En otras palabras, según esta tesis más garantista, la punibilidad de los jefes no ha de subordinarse a la contribución que ellos han dado en el trazado del programa criminal genérico de la asociación terrorista o mafiosa, sino a la concreta contribución ofrecida por ellos en sede de instigación de los específicos delitos-fin cometidos por los miembros de la asociación.

\subsection{El problema del "concurso externo" en el delito de asociación ilícita.}

Por lo que en cambio concierne a las hipótesis del denominado "concurso externo" de personas en el delito de asociación ilícita, antes que nada es preciso evidenciar hasta qué punto resulta problemático reconocer la configuración de conductas de concurso (externo) de personas en los delitos de asociación, que no constituyan al mismo tiempo conductas

\footnotetext{
${ }^{81}$ MOROSINI, Piergiorgio, Il concorso di persone e le organizzazioni complesse, ponencia realizada el 29 de octubre de 2008 con ocasión del encuentro de estudios penales organizado en Roma por el Consejo Superior de la Magistratura (CSM) desde el 27 al 31 de octubre de 2008 "para los magistrados titulares nombrados por el DM 6.12.2007”, p. 1 del texto en borrador. La sentencia aludida corresponde a la de 26 de febrero de 1983 de la Corte di Assise de Génova.

${ }^{82}$ Cfr., por ejemplo, Corte de Casación, 30 de enero de 1992.

${ }^{83}$ Cfr. MOROSINI, Piergiorgio, Il concorso di persone e le organizzazioni complesse, cit. nota $\mathrm{n}^{\circ} 81, \mathrm{p} 12$; allí mismo, para referencias adicionales.

${ }^{84}$ Cfr., en particular, con referencia al art. 416 bis, Corte de Casación, sección V, sentencia de 6 de junio de 2001, en revista Cassazione penale, 2002, pp. 975 y ss., con comentario de sentencia de MELILLO, Giovanni, "Sulla responsabilità dei singoli componenti della "cupola" di "cosa nostra" per il delitti decisi dall'organismo di vertice", pp. 989 y ss.; igualmente Casación, sección VI, 16 febrero de 2006, en Rivista penale, 2006, pp. 1338 y ss.
} 
expresivas de participación directa en la asociación. No obstante lo anterior, la evidente conveniencia de castigar algunas formas de "contigüidad complaciente" con la asociación criminal, destinadas a radicarla en el territorio y a facilitar sus actividades, ha decidido la fortuna del "concurso externo", especialmente con relación al delito de asociación mafiosa. Así, por ejemplo, como fuera referido por un magistrado de Palermo recientísimamente, ${ }^{85}$ se ha imputado "concurso externo" contra algunos jueces presuntamente culpables de haber emitido sentencias favorables para "hombres de mafia"; igualmente contra empresarios que, aun sin formar directamente parte de la asociación criminal, por las más variadas razones (temor, el deseo de complacer a sujetos influyentes en el contexto social local, etc.) proporcionaban una sala para las reuniones de los asociados; contra políticos que estipulaban "pactos electorales de canje" médicos que, aun si aparecer como "orgánicos" para la mafia, curaban a jefes mafiosos prófugos; incluso contra un sacerdote que todos los días concurría a la casa de un capomafia prófugo, para celebrar allí la misa.

Obviamente la extrema ductilidad del "concurso externo", la capacidad de esta figura elaborada por la jurisprudencia para atacar formas peligrosísimas de colusión con las asociaciones criminales, ha favorecido su transplante desde el contexto mafioso al propio del terrorismo. De esta forma, con el advenimiento y el incremento del terrorismo internacional ligado al extremismo islámico, ha sido considerada como hipótesis de concurso externo la mera tenencia de material de propaganda del terrorismo, ${ }^{87}$ e incluso "actitudes de mera adhesión psicológica a la asociación, deducibles a partir de un lenguaje antagonista respecto a la cultura occidental". 88

Ahora bien, es fácil entender qué, por su extrema complejidad, también los casos judiciales en materia de concurso externo en los delitos de asociación están fatalmente expuestos a oscilaciones interpretativas, diversamente influenciadas por las actitudes más o menos garantistas de los magistrados, así como del mayor o menor "clima de emergencia" que se respire en un determinado momento histórico al interior del contexto social.

No debe por tanto sorprender si - en relación con algunos procesos que han visto como imputados a los sujetos más variados desde el punto de vista del rol social que desempeñan, pero mancomunados por el hecho de hallarse en una posición de más o menos querida cercanía con temibles asociaciones ilícitas o con sujetos a ellas pertenecientes - los veredictos de primera instancia, de apelación o de casación, se han caracterizado por una alarmante alternancia de condenas y absoluciones. Al respecto, han resultado emblemáticos los casos Carnevale, Contrada y Mannino.

\footnotetext{
${ }^{85}$ MOROSINI, Piergiorgio, precisiones ofrecidas despues de concluir su ponencia Il concorso di persone e le organizzazioni complesse, supra cit. nota $\mathrm{n}^{\circ} 50$.

${ }^{86}$ En virtud de tales pactos se solicita a la asociación criminal, en particular, procurar votos, prometiendo a cambio favores de diversa naturaleza en caso de victoria en las elecciones. Cfr. DE FRANCESCO, Giovannangelo, "Dogmatica e politica criminale nei rapporti tra concorso di persone ed interventi normativi contro il crimine organizzato", Riv. it. dir. proc. pen., 1994, pp. 1285 y ss.

${ }^{87}$ En particular, revistas que celebran los atentados y el "martirio". Cfr. Corte de Casación, 13 de octubre de 2004, Laagoub; Corte de Casación, 9 de febrero de 2005, Benameur y otros.

${ }^{88}$ MOROSINI, Piergiorgio, Il concorso di persone e le organizzazioni complesse, cit. nota n ${ }^{\circ} 81$, p. 3.
} 
Polit. crim. Vol. 5, No 9 (Julio 2010), Art. 2, pp. 68-113.

[http://www.politicacriminal.cl/Vol_05/n_09/Vol5N9A2.pdf]

Corrado Carnevale ${ }^{89}$ fue Presidente de la primera sección de la Suprema Corte de Casación y en los años ' 80 estuvo bajo los reflectores por haber absuelto por vicios de forma a un gran número de imputados en importantes procesos de mafia. Acusado de "ajustar los procesos" por un arrepentido de mafia y sometido en 1993 a proceso por concurso externo en asociación mafiosa, a partir del mismo año fue suspendido de sus funciones y del goce de remuneraciones. Absuelto en primera instancia al final de los años '90, en el año 2001 fue condenado por la Corte de Apelaciones de Palermo a seis años de cárcel y a la inhabilitación perpetua para el ejercicio de cargos públicos. Sin embargo, en 2002 la Corte de Casación lo absolvió en definitiva de todo cargo en su contra, permitiéndole de esta forma volver a desempeñar sus funciones de magistrado de último grado, pero sin con esto poner fin a las polémicas ${ }^{90}$ en torno a un juez que, en el curso de su carrera, anuló cientos de sentencias por cuestiones de forma - decisiones consideradas por muchos como veniales - y que no abstuvo de ultrajar, aun después de su muerte, a los jueces Falcone y Borsellino, ${ }^{91}$ asesinados con uso de explosivos por la mafia a comienzos de los años ' 90 , y desde entonces considerados como el símbolo heroico de un sentido del deber indiferente frente a todo riesgo. ${ }^{92}$

Aún más largo ha sido el itinerario judicial de Bruno Contrada, ${ }^{93}$ un alto funcionario de la Policía, quien en 1996 fue condenado en primera instancia a diez años de reclusión, para luego, en 2001, ser absuelto de todo cargo por la Corte de Apelaciones de Palermo, en virtud de una sentencia que luego, en el 2002, sería anulada por la Corte de Casación. En consecuencia, en el 2006 fue nuevamente procesado y condenado a diez años de reclusión por una sección diversa de la Corte de Apelaciones de Palermo. La posterior confirmación, en el 2007, de la sentencia condenatoria de apelación por parte de la Corte de Casación no puso en todo caso fin a este increíble itinerario judicial, el que continuó en sede de ejecución de la pena, entre solicitudes de indultos rechazadas, instancias de revisión del proceso (también rechazadas), e instancias de suspensión de la pena por motivos de salud (también ellas terminadas en nada). Finalmente, en julio de este año, se concedió el arresto domiciliario por motivos de salud a un hombre que a esta altura es el espectro de si mismo.

Finalmente, Calogero Mannino, conocido político italiano designado ministro de Estado en varias ocasiones en los años '80 y 90, fue arrestado en 1995 por un presunto acuerdo con la mafia (votos a cambio de favores). Fue dejado en libertad en 1997 por caducidad de los plazos de custodia cautelar y luego absuelto en primera instancia en 2001, por insuficiencia

\footnotetext{
${ }^{89}$ Con respecto al cual cfr., de reciente, CORDA, Mario, Corrado. L'incredibile storia del giudice Carnevale, Milán: 2008.

${ }^{90}$ Cfr. BOLZONI, Attilio \& D'AVANZO, Giuseppe, La giustizia e cosa nostra: il caso Carnevale tra delitti e impunità, Milán: 1995.

${ }_{91}$ Cfr., por todos, Corrado Carnevale, en http://it.wikipedia.org/wiki/Corrado_Carnevale

${ }^{92}$ La bibliografía sobre Giovanni Falcone y Paolo Borsellino es interminable. Cfr., por todos, AYALA, Giuseppe, Chi ha paura muore ogni giorno. I miei anni con Falcone e Borsellino, Milán: 2008; FALCONE, Anna, FALCONE, Maria, ZINGALES, Leone, Giovanni Falcone, un uomo normale, 2007; LA LICATA, Francesco, Storia di Giovanni Falcone, Milán: 2003; LUCENTINI, Umberto, Paolo Borsellino. Il valore di una vita, Milán: 1994; ZINGALES, Leone, Paolo Borsellino - una vita contro la mafia, Arezzo: 2005.

${ }^{93}$ Con respecto al caso Contrada cfr., aunque definitivamente no actualizados, los libros de CAVALLARO, Felice, (Il caso Contrada : tra Stato e cosa nostra, Soveria Mannelli: 1996) y de NICASTRO, Franco, (Mafia, 007 e massoni: il caso Contrada, le trame di boss, poteri occulti e servizi segreti, Palermo:1993).
} 
de pruebas en su contra. Resultaría luego condenado en apelación a cinco años y cuatro meses de reclusión, en virtud de una sentencia que luego sería anulada por la Corte de Casación por falta de motivación. Finalmente fue nuevamente absuelto el 22 de octubre de 2008 por la Corte de Apelaciones de Palermo. Actualmente miembro del Parlamento italiano, Calogero Mannino es la última prueba viviente de cuánto pueda ser incierta la frontera, en el ámbito de los delitos de asociación, entre inocencia y culpabilidad.

En definitiva entonces, se puede concluir esta sección afirmando que el examen de la jurisprudencia italiana en materia de criminalidad organizada de tipo terrorista y mafioso confirma los rasgos asumidos en los mismos ámbitos por la legislación de sector. Una y otra se revelan - al menos en principio - expresivas de un "derecho penal de lucha contra la maxi-criminalidad", 94 caracterizado por la tendencia a asegurar, por razones de seguridad institucional, colectiva e individual, una particular severidad/eficacia de la respuesta punitiva aplicada a los autores de delitos que, a causa de su gravedad extrema, suscitan gran alarma social. Asimismo, ambas legislaciones manifiestan un endurecimiento general del sistema, marcado por la erosión de las garantías en los casos en los que el delito cometido se circunscriba a una fenomenología criminal actual, insidiosa, obstinada, difusa y, por tanto, difícil de contrarrestar.

\subsection{La evolución de la política judicial en materia de criminalidad organizada de tipo económica y política.}

Muy distinta ha sido, por el contrario, la evolución de la política judicial en materia de criminalidad organizada de tipo económica y política (la que en todo caso también tendría las características antes señaladas). En extrema síntesis, se puede decir que, por toda una serie de razones - entre las que destacaban la insuficiente conciencia de la extrema peligrosidad social de semejantes formas de criminalidad $^{95}$ y la objetiva dificultad para obtener material probatorio a este respecto - hasta el inicio de los años ' 90 del siglo pasado fueron muy escasos los procesos penales relativos a ilícitos económicos, ilícitos políticos o a la conmixtión entre unos y otros.

Viceversa, como se ha dicha anteriormente, ${ }^{96}$ también tras algunas eficaces campañas de prensa y del arribo de partidos políticos nacidos con el declarado objetivo de oponerse a los "robos" cometidos por las clases dirigentes, a partir de los primeros años de los '90, todos los ciudadanos italianos alcanzan finalmente la conciencia de lo difuso y dañino de los mencionados fenómenos criminales. Ello favorece un cambio en la actitud de la magistratura encargada de las investigaciones - o de al menos una parte de ella -, la que comienza a concentrar su actividad en tales fenómenos. Muy luego, también con la complicidad de algunas circunstancias afortunadas, se esclarecen una serie de escándalos circundados de connotaciones penales, que harán pasar a la historia este período como la

\footnotetext{
${ }^{94}$ Con respecto al cual cfr., en particular, DONINI, Massimo, "Diritto penale di lotta vs. diritto penale del nemico", en: KOSTORIS, Roberto E., ORLANDI, Renzo (coord.), Contrasto al terrorismo interno e internazionale, Turín: 2006, pp. 19 y ss.

${ }^{95}$ Cfr. CHITI, Edoardo \& MATTARELLA, Bernardo Giorgio,"La sicurezza europea”, Rivista trimestrale di diritto pubblico, 2008, pp. 305 y ss.

${ }^{96}$ Cfr. supra, par. 10, letra $c$ ).
} 
Polit. crim. Vol. 5, No 9 (Julio 2010), Art. 2, pp. 68-113.

[http://www.politicacriminal.cl/Vol_05/n_09/Vol5N9A2.pdf]

era de "tangentopoli" importantes empresarios y políticos (aunque sólo en algunos casos se llegase a condenas definitivas).

Según los críticos de "tangentopoli" (casi siempre en relación de parentesco, de negocios o de trabajo con los imputados), durante este período la magistratura investigadora especialmente en Milán, pero no sólo - moldeó su accionar a una actitud de "lucha" contra la criminalidad económico-política, en particular caracterizada por un recurso impropio a la prisión preventiva como medio para forzar confesiones y para realizar una suerte de anticipación de la pena. A los jueces de "tangentopoli" se les ha reprochado también el haber concentrado la propia atención sólo en los ilícitos cometidos por algunos partidos políticos, terminando con ello por favorecer indirectamente a otros partidos.

Más allá de tales críticas, normalmente carentes de todo fundamento, "tangentopoli" fue de todas formas un breve período. De hecho, en el trascurso de pocos años, la acción judicial de oposición a la conmixtión entre criminalidad económica y política ha progresivamente perdido su impulso. A ello han contribuido múltiples causas: una constante obra de contrainformación conducida en gran medida por los medios de comunicación y el poder político, encaminada a la "criminalización" de una magistratura considerada culpable de condicionar, por vía judicial, la vida política italiana; la aprobación de reformas más o menos unívocamente dirigidas a neutralizar la acción de los jueces y a minimizar el riesgo de cárcel para los white-collar $;^{98}$ el hecho de que la antes mencionada acción judicial haya perdido progresivamente el original apoyo popular, también a causa de la generalizada toma de conciencia en cuanto a que endurecer la lucha contra la criminalidad económica significaba no sólo atacar a los santuarios del poder político y económico, sino que significaba también atacar o correr el riesgo de atacar a los pequeños ilícitos económicos de comerciantes o profesionales: en definitiva, de una no pequeña parte de los ciudadanos.

A esta altura, considerando los limitados espacios dejados a la acción penal en el ámbito económico-político, la casi segura prescripción de los hechos imputados, el modestísimo nivel de efectividad de la aplicación de la pena ${ }^{99}$ (incluso respecto a los procesos concluidos), es hoy prácticamente imposible encontrar a un órgano de persecución dispuesto a empeñarse en una acción seria de oposición a los delitos de corrupción en

\footnotetext{
${ }^{97}$ El término Tangentopoli [ndt: con la voz "tangente" - cuota o alícuota - se alude a las "comisiones" ilícitamente pagadas a funcionarios públicos o a particulares a cambio de la obtención de un determinado servicio o beneficio, como puede ser la obtención de concesiones, licitaciones, etc.] — acuñado tras una serie de procesos penales relativos a casos de corrupción y de financiamiento ilícito, con fondos negros, de partidos políticos — alude al complejo sistema de colusión ilegal entre poder económico y poder político, desvelado en el curso de la investigación judicial denominada "Manos limpias" [Mani pulite]; se trató de una investigación que, a causa del enorme escándalo que suscitó, condujo de hecho a una suerte de revolución incruenta que marcó en Italia el fin de la denominada "Primera República" y la llegada de la "Segunda República".

${ }^{98}$ Por ejemplo, a través de la despenalización de los delitos que afectan la moneda o los medios de pago, del giro de cheques sin fondos, del uso de información privilegiada por sujetos no insiders, de muchas hipótesis de evasión tributaria y de falsedades contables en el balance.

99 Por una serie de motivos imposibles de resumir en esta sede. Sobre el argumento cfr., ampliamente, DAVIGO, Piercamillo, MANNOZZI, Grazia, La corruzione in Italia. Percezione sociale e controllo penale, Roma-Bari: 2007, en particular pp. 304 y ss.
} 
dichos ámbitos. Y esto acontece en medio de la indiferencia de la opinión pública, ya amnésica respecto a su precedente actitud de intransigencia. Como ha sido mencionado al final de la sección 10, la demanda colectiva de seguridad - con la complicidad de la prensa - ignora o, en todo caso, subvalora los deletéreos efectos producidos en la sociedad civil por la delincuencia económica y política, concentrando así su atención en formas muy diversas - pero igualmente capilares - de criminalidad.

\section{La política criminal italiana en materia de seguridad privada: la lucha contra la criminalidad callejera.}

En las últimas décadas, en Italia la demanda de reforzamiento de la respuesta penal por razones de seguridad no ha sido provocada sólo por la vistosa aparición de la criminalidad terrorista y mafiosa, sino también por la multiplicación de algunos delitos comunes (hurtos, robos en lugares habitados, asaltos, vandalismo, micro-tráfico de droga, agresiones en lugares públicos, especialmente en los estadios), la mayoría de las veces cometidos por personas pertenecientes a bien precisos grupos, clases sociales o categorías (inmigrantes, desempleados, manifestantes o protestantes de diversas extracciones políticas, hooligans, etc.). Ciertamente no se ha tratado sólo de un fenómeno italiano, sino de un fenómeno que, aunque en distintos grados y con algunos desfases temporales, ha tenido ingerencias en muchísimos países, en particular en todos los países de Europa occidental; países éstos que primero se vieron envueltos en un proceso de crecimiento económico que se tornó particularmente evidente a partir de los años ' 60 del siglo pasado, y que sucesivamente se vieron expuestos a una inmigración descontrolada y en continuo aumento. El consiguiente crecimiento del sentido de inseguridad y de la alarma social, ${ }^{100}$ no raramente acompañados por la sensación de que los órganos institucionales previstos para contrarrestar los delitos en cuestión, ${ }^{101}$ no hicieren todo lo que estaría en sus medios, ${ }^{102}$ ha inducido en variadas ocasiones al legislador italiano a aprobar reformas encaminadas a potenciar los efectos de prevención general de las normas penales asociadas a algunas de las formas más frecuentes y preocupantes de la criminalidad común. Así, ya desde la primera mitad de los años '70, se han aumentado las penas de algunos delitos como el robo agravado; ${ }^{103}$ se han introducido nuevos tipos dirigidos a atacar los delitos cometidos durante las manifestaciones públicas; ${ }^{104}$ se ha dispuesto el incremento de la severidad de la regulación en materia de armas, ${ }^{105}$ de manera de obstaculizar no sólo la entonces creciente delincuencia terrorista, sino también las formas tradicionales de criminalidad contra la persona y el patrimonio. ${ }^{106}$

\footnotetext{
100 Cfr. BARBAGLI, Marzio, “Introduzione. Perché è diminuita la criminalità negli Stati Uniti?”, en: BARBAGLI, Marzio, (coord), Perché è diminuita la criminalità negli Stati Uniti?, Boloña: 2000, p. 11, para referencias bibliográficas adicionales.

${ }^{101}$ Se alude, antes que nada, a la policía y a los jueces.

${ }^{102}$ Al respecto, cfr., si bien desde posiciones muy distintas, FENECH, Georges, Tolleranza zero, cit. nota $n^{\circ}$ 75, pp. 28 y ss.; PEPINO, Livio, “La città e l'impossibile supplenza giudiziaria”, Questione giusitizia, 1999, p. 791, nt. 1, con referencias bibliográficas adicionales.

${ }^{103}$ Ley n. 497, 14 de octubre 1974.

${ }^{104}$ Ley n. 110, 18 de abril de 1975, n. 110; ley n. 152, 22 de mayo de 1975.

${ }^{105}$ Ley n. 497, 14 de octubre de 1974; ley n. 110, 18 de abril de 1975; ley n. 152, 22 de mayo de 1975; ley n. 533, 8 de agosto de 1978; ley n. 191, 18 de mayo de 1978.

${ }^{106}$ Cfr. PALAZZO, Francesco, La recente legislazione penale, cit. nota $n^{\circ} 66$, pp. 37-38.
} 
Polit. crim. Vol. 5, No 9 (Julio 2010), Art. 2, pp. 68-113.

[http://www.politicacriminal.cl/Vol_05/n_09/Vol5N9A2.pdf]

Cualesquiera que hayan sido los efectos de aquellas reformas y de otras sucesivas en las tasas de las diversas formas de "criminalidad callejera", lo cierto es que la preocupación colectiva respecto a estas últimas evidentemente no ha disminuido; por el contrario aunque, en opinión de algunos, los episodios de delincuencia urbana habrían disminuido en los últimos años en Italia ${ }^{107}$ o, en todo caso, habrían dejado de crecer al ritmo precedente en estos años tal preocupación ha aumentado ulteriormente, junto al temor hacia los extracomunitarios y, más en general, hacia los "diversos". ${ }^{108}$ A fomentar adicionalmente la alarma social, han contribuido luego una parte de los órganos de información (televisión y periódicos), con frecuencia preocupados de asentar la idea de que la seguridad colectiva está comprometida, de manera prácticamente exclusiva, por la criminalidad común y por las formas de perversión sexual. ${ }^{109}$ En este clima de general alarma "selectiva" es posible situar, por ejemplo, la reforma en materia de violencia sexual de $1996,{ }^{110}$ la reforma de 2001 sobre la base de la cual fue fuertemente elevado el grado mínimo de la pena privativa de libertad del delito de hurto, amén de haberse introducido los nuevos tipo de "hurto en habitación" y "hurto con tirón" [ $n d t$ : análogo a nuestro robo por sorpresa], castigados con pena de uno a seis años de reclusión, los que se vuelven tres a diez años en presencia de algunas circunstancias agravantes. ${ }^{111}$

Sin embargo, reformas de este clase - por lo demás, de efectos preventivos inciertos - no pueden por cierto aplacar a una opinión pública que ha sido inducida a considerar el uso de la fuerza como la única respuesta eficaz contra la criminalidad callejera y contra la perversión sexual, descuidando en cambio las políticas de tipo social; políticas éstas que, por lo demás, hoy se han vuelto particularmente problemáticas a causa de la generalizada y persistente crisis económica, de la exigencia de limitar el crecimiento de la deuda pública, y de la falta de conciencia en cuanto a que los costos para la colectividad de las formas difusas de criminalidad común, no son inferiores a los costos de algunas muy importantes políticas sociales (como, por ejemplo, el mejoramiento del alumbrado público, la creación de lugares de cultura y recreo para los jóvenes, de centros idóneos para la prevención y superación de la dependencia de las drogas, de agencias para el sostén e integración social de los inmigrantes).

Y con esto se llega a una ulterior y muy reciente oleada de nuevas leyes encaminadas a responder a la demanda colectiva de seguridad, incluso a costa de vulnerar el principio de proporción y/o de igualdad, de volver a poner en discusión algunas libertades y garantías fundamentales. Emblemáticas resultan a este respecto la reforma de 2005 en materia de reincidencia ${ }^{112}$ y la reforma de 2006 en materia de legítima defensa: ${ }^{113}$ la primera dirigida a

\footnotetext{
${ }^{107}$ Cfr., por ejemplo, FERRAJOLI, Luigi, “Crisi della legalità e diritto penale minimo", en: Diritto penale minimo, cit. nota $\mathrm{n}^{\circ} 50$, p. 13 .

${ }^{108}$ Es decir, los sujetos pertenecientes a las clases consideradas por los ciudadanos comunes como "clases sociales peligrosas". Al respecto, cfr., en términos críticos, FERRAJOLI, Luigi, Principia iuris, vol. II, Teoria della democrazia, Bari - Roma: 2007, pp. 372 y ss.

${ }^{109}$ Cfr., ampliamente y por todos, FERRAJOLI, Luigi, Crisi della legalità e diritto penale minimo, cit. nota $\mathrm{n}^{\circ} 50, \mathrm{pp} .12$ y ss.

${ }^{110}$ Ley n. 66, 15 de febrero de 1996.

${ }^{111}$ Ley n. 128, 26 de marzo de 2001.

${ }^{112}$ Ley n. 251, 5 de diciembre de 2005.

${ }^{113}$ Ley n. 59, 13 de febrero de 2006.
} 
proteger a la colectividad contra los sujetos ya marcados por sus comportamientos antisociales (y por tanto merecedores antes que nada de un tratamiento para su neutralización, en virtud de la preclusión de la suspensión condicional de la pena, de las medidas alternativas a la detención, de la admisión a algunos procedimientos simplificados $\mathrm{y}$ a beneficios en el plano sancionatorio vinculados a dichos procedimientos; la segunda reforma, pensada para afirmar la primacía de la seguridad doméstica por sobre los derechos fundamentales de quien, introduciéndose en una habitación ajena, determina un peligro de agresión.

Aun más emblemática resulta, si es que todavía posible, la recientísima reforma de 2008 que ha introducido la agravante de la clandestinidad. ${ }^{114}$ En realidad, se trata de una agravante caracterizada por un escaso rendimiento práctico $^{115}$ y aun con aire de inconstitucionalidad, ${ }^{116}$ pero tendiente a tranquilizar a la colectividad con respecto al hecho de que el gobierno se está movilizando contra la inmigración clandestina, en cuanto fenómeno expresivo de desobediencia a la ley, e incluso de posibles rasgos criminógenos.

\section{La política criminal europea en materia de seguridad. El rol del Consejo de Europa y de la Unión Europea.}

Sin embargo, como ya ha sido recordado, en Europa las relaciones entre seguridad y derecho penal no se desarrollan sólo a través de la actividad de los legisladores y de los jueces nacionales, sino también por medio de la actividad de organizaciones trans- o supraestatales. Se alude una vez más al Consejo de Europa y a la Unión Europea, ambas instituciones tradicionalmente preocupadas del problema de la seguridad, entendida tanto en sentido amplio (como protección frente a amenazas a los más diversos bienes e intereses individuales y colectivos), ${ }^{117}$ como, sobre todo, en sentido restringido (como protección sólo frente a peligros de alta gravedad y de origen criminal). ${ }^{118}$

\subsection{Convenciones del Consejo de Europa.}

En cuanto al Consejo de Europa, del que ya se han explicado los orígenes y sus finalidades, ${ }^{119}$ es indudable que, desde un punto de vista cronológico, precisamente algunas de sus convenciones constituyen los primeros instrumentos internacionales expresivos de

\footnotetext{
${ }^{114}$ Cfr. el decreto ley de 23 de mayo de 2008 sobre "Medidas urgentes en materia de seguridad pública», convertido en la ley de 25 de julio de 2008, la que introdujo el art. 61 n. 11 bis c.p., en base al cual la pena es agravada "si el hecho es cometido por un sujeto que se encuentre ilegalmente en el territorio nacional".

${ }^{115}$ En atención a la posibilidad del juez de declarar cualquier circunstancia atenuente como prevalente, por sobre tal agravante.

${ }^{116}$ Por violación del principio de igualdad. Cfr., por todos, DONINI Massimo, Sicurezza e diritto penale, cit. nota n 30, pp. 3562 y ss.; PAGGI, Marco, "Pacchetto sicurezza - Un primo commento alle disposizioni previste dal decreto legge", en http:/www.meltingpot.org/articolo12724.html

${ }^{117}$ Cfr. ORTEGA ÁLVAREZ, "Hacia un concepto integral de seguridad europea", en: ORTEGA ÁLVAREZ, Luis, (coord.), La seguridad integral europea, Valladolid: 2005, pp. 25 y ss.

${ }^{118}$ Sobre el tema cfr., también para ulteriores distinciones, CHITI, MATTARELLA, La sicurezza europea, cit. nota $\mathrm{n}^{\circ} 95$, pp. 305 y ss.

${ }^{119}$ Cfr. supra, par. 9.
} 
Polit. crim. Vol. 5, No 9 (Julio 2010), Art. 2, pp. 68-113.

[http://www.politicacriminal.cl/Vol_05/n_09/Vol5N9A2.pdf]

una política criminal europea encaminada, simultáneamente, al mejoramiento de las formas de cooperación en materia penal y a la armonización de los sistemas penales nacionales. ${ }^{120}$

En particular, entre las convenciones específicamente pensadas por razones de seguridad, en primer lugar bastará recordar aquí la Convención europea para la represión del terrorismo, de 27 de enero de 1977, la que tiende en particular a favorecer la cooperación judicial entre los Estados, en materia de delitos de carácter terrorista, excluyendo que éstos puedan considerarse como delitos políticos o inspirados en razones políticas, y por tanto excluyendo que ellos puedan beneficiarse de las garantías tradicionalmente concedidas a los respectivos autores, siendo el rechazo de la extradición el primero de dichos beneficios. $^{121}$

También la Convención europea relativa al resarcimiento de las víctimas de delitos violentos, de 24 de noviembre de 1983, teniendo precisamente como objetivo asegurar y desarrollar mecanismos de resarcimiento a favor de las víctimas por parte de los Estados donde los antes mencionados delitos se han ejecutado, apunta a responder de algún modo a la demanda de seguridad: si bien ya no a través de la prevención de los delitos, al menos mediante formas de indemnización para las víctimas.

La misma Convención europea, de 19 de agosto de 1985, sobre la violencia y los desórdenes de los espectadores durante las manifestaciones deportivas - especialmente en los partidos de fútbol -, en la medida que solicita a los Estados miembros la adopción de leyes que prevean penas apropiadas para las personas que hubieren sido reconocidas como culpables de delitos cometidos por los espectadores de eventos deportivos, persigue claramente una finalidad de seguridad: precisamente aquella consistente en la prevención y represión de hechos de hooliganismo.

Además, con el paso de los años, algunas convenciones del Consejo de Europa ya no se han limitado a prever obligaciones genéricas para los Estados contrayentes con respecto a comportamientos prohibidos y a las respectivas sanciones, sino que de a poco han ido asumiendo contenidos más específicos o detallados. En este sentido, especialmente a partir de la "Convención para la protección del ambiente a través del derecho penal" de 1998, las instancias internacionales han intensificado el recurso a textos normativos que contienen tanto la gama de hechos subsumibles en los tipos penales, como la indicación de las características de las clases de sanciones aplicables a los hechos en cuestión y de las funciones que ellas son llamadas a desarrollar. Piénsese, por ejemplo, en la "Convención penal sobre la corrupción" de 1999, a la "Convención sobre la criminalidad informática" de 2001, a la "Convención para la prevención del terrorismo" de 2005, a la "Convención sobre la lucha contra la trata de seres humanos" de 2005, a la "Convención sobre el lavado de

${ }^{120}$ Cfr., entre otros, BERNARDI, Alessandro, "L'harmonisation des sanctions en Europe", en: DELMASMARTY, Mireille, PIETH Mark, SIEBER, Ulrich, (coord.), Les chemins de l'harmonisation pénale, Paris: 2008, pp. 300 y ss.; MANACORDA, Stefano, "L'armonizzazione dei sistemi penali: una introduzione", en: La giustizia penale italiana nella prospettiva internazionale, Milano: 2000, p. 46.

${ }^{121}$ El 15 de mayo de 2003 se adoptó un Protocolo de tal convención, el que amplía el grupo de delitos calificables como terroristas. 
dinero, búsqueda, incautación y confiscación de los productos del delito y sobre el financiamiento del terrorismo" de 2005.

Por otra parte, más allá del actual e intensificado uso por parte del Consejo de Europa de convenciones de carácter penal de contenido cada vez más preciso, subsiste el hecho de que la vigencia de estas convenciones al interior de los Estados miembros, depende de su voluntad. Además, la misma elaboración de tales instrumentos, su entrada en vigor y su eventual modificación, se demuestran sumamente complejas: de hecho, la primera de dichas fases implica negociaciones normalmente desgastantes, mientras que la segunda y la tercera fase mencionadas requieren tanto la firma como la ratificación por parte de un cierto número de Estados miembros, conforme a sus respectivas reglas constitucionales. Por fin, el Consejo de Europa carece del todo de órganos jurisdiccionales propios, ${ }^{122}$ de manera que resulta imposible ofrecer una interpretación centralizada del texto de tales actos jurídicos, y contra eventuales incumplimientos por parte de los Estados miembros no resta más que la vía política como medio de reacción. Por todas estas razones, en el proceso de cooperación y armonización sancionatoria realizado en Europa a iniciativa de las organizaciones internacionales de carácter regional y con el libre consentimiento de los respectivos Estados miembros, el rol principal corresponde sin duda a la Unión Europea, a través de los instrumentos de su "tercer pilar".

\subsection{La política criminal común del “tercer pilar” de la Unión Europea.}

Afrontando entonces el tercer pilar UE y los instrumentos penales por él previstos con el fin de salvaguardar la seguridad de la colectividad y de los individuos, resulta necesario subrayar de inmediato que, a partir de la mitad de los años '90, tales instrumentos han permitido la elaboración de una verdadera "política criminal común", para "un control estrecho de los desarrollos de la integración europea en algunos sectores relevantes",123, como la criminalidad organizada y las otras formas de criminalidad transnacional (art. 29, inc. 2, Tratado UE); ${ }^{124}$ sectores éstos, en los cuales políticas o intervenciones puramente "internas" resultarían en principio ineficaces. ${ }^{125}$ Todo lo anterior, con miras a la afirmación de un "espacio de libertad, seguridad y justicia" del que puedan servirse todos los ciudadanos de la Unión.

Ahora bien, considerando que la Unión Europea, en el ámbito de su tercer pilar, posee una suerte de competencia penal indirecta ${ }^{126}$ en bien determinados y circunscritos sectores, debe decirse que los instrumentos "anticriminales" utilizables en el ámbito del tercer pilar son

\footnotetext{
${ }^{122}$ Un caso a parte es el de la Convención europea de los derechos del hombre, un instrumento del Consejo de Europa, dotado de jueces destinados al control del respeto de las normas contenidas en la Convención.

${ }^{123}$ MASTROIANNI, Roberto, "Il controllo della Corte di giustizia in relazione agli atti del I e del III pilastro: riflessi in materia penale", p. 4, en http://appinter.csm.it/incontri/relaz/9908.pdf.

${ }^{124}$ En particular, el terrorismo, la trata de seres humanos y los delitos contra los menores de edad, el tráfico ilícito de drogas y de armas, el cohecho y el fraude.

${ }^{125}$ Cfr., de reciente, DUTHEIL DE LA ROCHERE, Jacqueline, Vers une conception nouvelle de la sécurité européenne, cit. nota $\mathrm{n}^{\circ} 27, \mathrm{p} .2$.

${ }^{126}$ En cuanto condicionada por el consenso de los Estados de la Unión Europea, en la medida que los actos normativos del tercer pilar se adoptan sobre la base de la regla de unanimidad.
} 
Polit. crim. Vol. 5, No 9 (Julio 2010), Art. 2, pp. 68-113.

[http://www.politicacriminal.cl/Vol_05/n_09/Vol5N9A2.pdf]

esencialmente de dos tipos: las convenciones y las decisiones-marco, hallándose en todo caso estas segundas en posición dominante con respecto a las primeras.

Las convenciones "de tercer pilar" revelan algunas diferencias significativas respecto a las convenciones del Consejo de Europa, pero obviamente presentan también, respecto a estas últimas, significativas analogías a nivel procedimental. De hecho, la elaboración de las dos importantes convenciones "de tercer pilar" aprobadas en la segunda mitad de los años '90 (es decir, la "Convención relativa a la tutela de los intereses financieros de las Comunidades europeas", adoptada en Bruselas el 26 de julio de 1995, ${ }^{127}$ y la "Convención relativa a la lucha contra la corrupción en la que estén involucrados funcionarios de las Comunidades europeas o de los Estados miembros de la Unión Europea", adoptada en Bruselas el 26 de mayo de 1997), se reveló casi igualmente larga y trabajosa ${ }^{128}$ que aquella propia de las convenciones del Consejo de Europa.

Lo anterior explica por qué en el ámbito del tercer pilar se abandonó muy pronto el recurso al instrumento de la convención, en favor de un instrumento normativo distinto y mucho más dúctil, denominado "decisión-marco".

Propuestas a iniciativa de la Comisión ${ }^{129}$ o de un Estado miembro, las decisiones-marco no gozan de eficacia directa y vinculan a los Estados EU sólo por lo que se refiere al objetivo a alcanzar, permaneciendo a salvo la competencia de los órganos nacionales con respecto a la forma y a los medios a utilizar para alcanzar dicho objetivo. ${ }^{130}$ Con respecto a las decisiones-marco (así como respecto a las convenciones, aunque con algunas variantes) los jueces de las Corte de Justicia UE cuentan con importantes competencias, especialmente en materia de interpretación y validez de tales cuerpos normativos, así como por lo que respecta a la constatación de las infracciones cometidas por los Estados en el momento de su aplicación. No obstante todo ello, sin embargo, el control de la Corte de Justicia sobre tales instrumentos jurídicos es incompleto; ello sobre todo porque los países miembros

\footnotetext{
${ }^{127}$ Cfr. LABAYLE, Henri, "La lutte anti-fraude et le troisième pilier”, en: GRASSO, Giovanni, (coord.), La lotta contro la frode agli interessi finanziari della Comunità europea tra prevenzione e repressione, Milán: 2000, p. 302; RIZZA, Cesare, "La sanzione delle violazioni da parte dei singoli di norme comunitarie dirette alla protezione degli interessi finanziari della Comunità nella giurisprudenza della Corte di giustizia", ivi, p. 115, nt. 68; SALAZAR, Lorenzo, "Cooperazione giudiziaria e lotta antifrode”, ivi, pp. 327 y ss.

128 También porque, conforme al art. 34 del Tratado de la Unión Europea, el Consejo sigue deliberando por unanimidad en relación con las convenciones instituidas en el ámbito del tercer pilar. Sobre el punto cfr. ADAM, Roberto, "La cooperazione in materia di giustizia e affari interni tra comunitarizzazione e metodo intergovernativo", en: Dir. Un. Eur., 1998, p. 486; igualmente, con acentos claramente críticos respecto al requisito de la unanimidad, O'KEEFFE, David, "Recasting the Third Pillar", Common Market Law Review, 1995, p. 904; CURTIN, D.M., POUW, J.M.F., "La coopération dans le domaine de la justice et des affaires intérieures au sein de l'Union européenne: une nostalgie d'avant Maastricht?", Rev. Marché un. eur., 1995, p. 30 .

${ }^{129}$ La Comisión - órgano ejecutivo de la Unión europea - está compuesta por los Comisionados europeos, elegidos de entre las más reconocidas personalidades de los Estados miembros, a los cuales no quedan sin embargo ligados por vínculos de representación. La duración del mandato de los miembros es de 5 años.

${ }^{130}$ Cfr. Art. 34, inc. $2^{\circ}$, letra $b$ ) Tratado UE.
} 


\section{BERNARDI, ALESSANDRO. "Seguridad y Derecho Penal en Italia y en la Unión Europea".}

pueden refutar la jurisdicción de la Corte, y en todo caso porque esta última no puede aplicar sanciones contra los Estados infractores. ${ }^{131}$

En cualquier caso, más allá de las persistentes carencias, es un hecho que las decisionesmarco han cumplido un rol fundamental en el desarrollo del espacio europeo de libertad, seguridad y justicia, en una doble perspectiva. En primer lugar, ellas han dado vida a un proceso de potenciamiento de la cooperación judicial y administrativa entre los países miembros, cuyas instancias más significativas han estado representadas por la creación de algunos textos normativos de actuación del principio de reconocimiento recíproco de las decisiones judiciales, así como por la elaboración de los textos creadores de Eurojust. ${ }^{132}$ En segundo lugar, las decisiones-marco han activado un importante fenómeno de acercamiento de las normas penales nacionales en numerosos sectores relevantes, ${ }^{133}$ respecto a los cuales las exigencias de seguridad advertidas por la Unión resultan las más elevadas. De esta forma se han adoptado, en particular, decisiones-marco dirigidas a armonizar las disposiciones de los países UE en materia de agresiones contra el medio ambiente, corrupción, criminalidad financiera, favorecimiento de la inmigración ilegal, explotación sexual de menores de edad y pornografía infantil, terrorismo, tráfico de estupefacientes, trata de seres humanos, lavado de dinero.

Esta breve panorámica sobre política criminal europea en materia de seguridad, nos permite poner en evidencia lo siguiente: que si bien, por una parte, los textos normativos creados a este efecto tienden obviamente a descuidar - aunque con alguna excepción ${ }^{134}$ - la criminalidad callejera, ${ }^{135}$ por otra parte, se ocupan de todas las formas más peligrosas de criminalidad organizada de carácter transnacional.

En particular, entre estas últimas, la Unión Europea ha concentrado su actividad hacia dos tipologías precisas de criminalidad organizada.

La primera es la criminalidad de carácter económico y político-administrativo (por el contrario, culpablemente descuidadas por la política criminal italiana). De hecho, por una parte, los fraudes comunitarios, en la medida que reducen los ingresos financieros necesarios para el funcionamiento de los órganos UE, constituyen un peligro real para la

\footnotetext{
${ }^{131}$ Cfr. BERNARDI, Alessandro, "Il ruolo del terzo pilastro UE nella europeizzazione del diritto penale. Un sintetico bilancio alla vigilia della riforma dei Trattati”, Rivista italiana di diritto pubblico comunitario, 2007, pp. 1171 y ss.

${ }^{132}$ Eurojust es un órgano de cooperación judicial permanente, el que tiene como objetivo el reforzamiento de la lucha contra las formas más graves de criminalidad, en particular aquella organizada, en la medida que sus actividades se extiendan a más de un Estado miembro.

${ }^{133}$ Cfr. MARGUE, Tung Lai, "La coopération en matière de prévention et de lutte contre le crime dans le cadre du nouveau troisième pilier", Rev. dr. Un. eur., 2000, p. 740; SALAZAR, Lorenzo, "La costruzione di uno spazio di libertà, sicurezza e giustizia dopo il Consiglio europeo di Tampere", Cass. pen., 2000, p. 1128; más recientemente BERNARDI, Alessandro, "Politiche di armonizzazione e sistema sanzionatorio penale", cit. nota $\mathrm{n}^{\circ} 57$, pp. 271 y ss.

${ }^{134}$ Piénsese en la antes citada Convención europea sobre la violencia y los desórdenes de los espectadores durante las manifestaciones deportivas, de Consejo de Europa de 1985.

${ }^{135}$ De hecho, la criminalidad callejera o común debería constituir un problema de orden público meramente interno; salvo en los casos en los que, como justamente acontece en los episodios de "hooliganismo", ella termine por asumir una relevancia transnacional.
} 
Polit. crim. Vol. 5, No 9 (Julio 2010), Art. 2, pp. 68-113.

[http://www.politicacriminal.cl/Vol_05/n_09/Vol5N9A2.pdf]

seguridad de la Unión (en el sentido de supervivencia económica); y por la otra, los fenómenos de corrupción comprometen por cierto el buen funcionamiento y el prestigio de los citados órganos. Se explican entonces muy bien las razones por las que la Unión Europea ha aprobado en variadas ocasiones, en el ámbito del tercer pilar, textos normativos mirantes a ejecutar, en la especie, profundos procesos de armonización de los preceptos y de las sanciones, caracterizados en general por un notable nivel de severidad.

La segunda es la criminalidad terrorista, en razón de la "necesidad de seguridad" fomentado por los atentados del 11 de septiembre de 2001 y por los atentados, de análoga matriz, efectuados el 11 de marzo de 2004 en la estación ferroviaria de Madrid y el 7 de julio del mismo año en una estación del metro de Londres. Tal "necesidad de seguridad" ha favorecido indudablemente la creación de una serie de textos normativos europeos, no sólo de tercer pilar, sino también del primero. Por lo demás, se trata de textos que, en ciertos casos, se fundan en algunas resoluciones ONU y que tienen como efecto inducir a los países UE a modificar sus legislaciones bajo el prisma de una generalizada erosión de las garantías individuales o incluso a realizar modificaciones semejantes de manera directa; es decir, sin la intermediación de los legisladores nacionales. ${ }^{136}$ De este modo, casi en toda Europa se han limitado las garantías de defensa, potenciado las medidas de prevención e introducido mecanismos que simplifican la expulsión de los extracomunitarios. ${ }^{137}$

En definitiva, a partir de lo expuesto hasta aquí, es posible afirmar que, tanto el Consejo de Europa como sobre todo la Unión Europea, desde hace ya muchos años han estado creando cuerpos normativos expresivos de una política criminal a veces demasiado enérgica, destinada a influir significativamente en los ordenamientos penales de los países miembros; ciertamente no favoreciendo respuestas punitivas inspiradas en el denominado "derecho penal del enemigo"138 y desde ya no legitimando algunas prácticas de intelligence totalmente irregulares (como por ejemplo las entregas extraordinarias - extraordinary renditions - de "elementos hostiles" sospechosos de participación en actos terroristas, ejecutadas por la CIA en muchos países UE con el tácito consentimiento de los gobiernos locales) ${ }^{139}$ pero en todo caso dando vida a un verdadero "derecho penal de lucha" "140 contra

\footnotetext{
${ }^{136}$ Ello acontece con los instrumentos normativos de primer pilar, denominados "reglamentos". De hecho, conforme al art. 110 inc. $2^{\circ}$ del Tratado de la Comunidad Europea, el reglamento "es obligatorio en todos sus elementos y directamente aplicable en cada Estado miembro".

${ }^{137}$ Cfr., por todos, BIN, Roberto, "Democrazia e terrorismo", cit. nota n 4, pp. 44 y ss., y la bibliografía allí referida en la nota 13 .

${ }^{138}$ Con respecto al cual cfr., en el marco de una bibliografía ya ilimitada, DONINI, PAPA (coord.), Diritto penale del nemico. Un dibattito internazionale, Milán: 2007; GAMBERINI, Alessandro, ORLANDI, Renzo (coord.), Delitto politico e diritto penale del nemico, Boloña: 2007; ZAFFARONI, Raúl, El enemigo en el derecho penal, Buenos Aires: 2007.

${ }^{139}$ Cfr. AMNESTY INTERNATIONAL, Voli segreti. Il rapporto del Consiglio d'Europa sulle operazioni coperte della CIA negli Stati Uniti, Turín: 2006; Risoluzione del Parlamento europeo sul presunto uso dei paesi europei da parte della CIA per il trasporto e la detenzione illegali di prigionieri (2006/2200(INI)), en Gazzetta Ufficiale dell'Unione Europea, C 287 E del 29 de noviembre de 2007, pp. 309 y ss.; FAVA, Claudio, Quei bravi ragazzi, Milán: 2007; por lo que se refiere específicamente a Italia, GIUPPONI, Tommaso F. "Stato di diritto e attività di intelligence: gli interrogativi del caso Abu Omar", Quaderni costituzionali, 2006, pp. 810 y ss.

${ }^{140} \mathrm{Cfr}$., supra, par. 11, nota $\mathrm{n}^{\circ} 94$.
} 
las formas de criminalidad organizada consideradas más peligrosas en el plano de la seguridad colectiva e individual.

Como veremos de inmediato, los jueces europeos de la Corte de Justicia UE contribuyen significativamente en la ejecución de tal política criminal, a veces potenciando sus efectos, en otras ocasiones neutralizando las consecuencias restrictivas de los derechos y de las libertades fundamentales.

\section{El rol de la Corte de Justicia UE en la concretización de la política criminal europea.}

Por lo que atañe específicamente a los textos UE ejecutivos de una política criminal tendiente a garantizar la seguridad en el interior del espacio común europeo, es preciso destacar el importante rol desempeñado por la Corte de Justicia europea. Dada la imposibilidad de profundizar en esta sede la contribución otorgada por la jurisprudencia UE para la concretización del derecho penal europeo, bastará en esta sede indicar tres distintas orientaciones jurisprudenciales que merecen ser consideradas, absolutamente fundamentales en este contexto.

\subsection{La interpretación de las normas nacionales conforme a la letra y objetivo de las decisiones-marco.}

La primera de tales orientaciones jurisprudenciales emerge de la sentencia Pupino de $2005,{ }^{141}$ luego confirmada por la sentencia Dall'Orto de $2007 .{ }^{142}$ En base a ella, los Estados y sus jueces tienen la obligación de interpretar las normas de derecho nacional, de manera lo más posiblemente conforme a la letra y el objetivo de las decisiones-marco.

Las virtudes de esta controvertida orientación - en la cual, para ser sinceros, la diferencia entre "interpretación conforme"" (ahora admitida para los actos del tercer pilar, como se ha dicho) y "eficacia directa"144 (explícitamente excluida del tercer pilar conforme al art. 34 par. 2, letra b) del Tratado UE, como se ha recordado $)^{145}$ corre el riesgo de extraviarse $^{146}$ consistirían esencialmente entonces en favorecer el alcance del resultado perseguido por las fuentes del tercer pilar, ${ }^{147}$ y en "disponer un paso adelante hacia la superación de la

\footnotetext{
${ }^{141}$ Tribunal de Justicia de la Unión Europea, Gran Sala, 16 de junio de 2005, causa C-105/03 (Pupino).

${ }^{142}$ Tribunal de Justicia de la Unión Europea, sentencia de 28 de junio de 2007, causa C-467/05 (Dall'Orto), con respecto a la cual cfr. MANES, Vittorio, "I rapporti tra diritto comunitario e diritto nazionale nello specchio della giurisprudenza della Corte di giustizia: approdi recenti e nuovi orizzonti", en ius17@unibo.it, p. 67.

${ }_{143}^{143}$ Dirigida a aplicar la norma interna, interpretándola a la luz de la norma europea.

${ }^{144}$ Dirigida a aplicar directamente la norma europea, incluso desaplicando - si fuese el caso - la norma interna que se halle en contradicción con aquella.

${ }^{145}$ Cfr., supra, par. 13 , nota $\mathrm{n}^{\circ} 130$.

${ }_{146} \mathrm{Al}$ respecto cfr., por todos, CALVANO, Roberta, "Il Caso Pupino: ovvero dell'alterazione per via giudiziaria dei rapporti tra diritto interno (processuale penale), diritto Ue e diritto comunitario", in http://www.associazionedeicostituzionalisti.it/materiali/anticipazioni/caso_pupino/index.html, par. 2; MANACORDA, Stefano, "Judicial activism dans le cadre de l'Espace de liberté, de justice et de sécurité de l'Union européenne", Revue de science criminelle et de droit pénal comparé, 2005, p. 747.

${ }^{147}$ Cfr. Tribunal de Justicia de la Unión Europea, sentencia 16 de junio de 2005, cit. nota nº 141, punto 43.
} 
Polít. crim. Vol. 5, № 9 (Julio 2010), Art. 2, pp. 68-113.

[http://www.politicacriminal.cl/Vol_05/n_09/Vol5N9A2.pdf]

distinción entre los tres pilares de la UE". ${ }^{148}$ Superación ésta que, según indica la experiencia madurada en los úlimos quince años de vida de la Unión europea, aparece por cierto oportuna, ${ }^{149}$ pero que sólo una reforma de tipo constitucional puede legitimar plenamente. ${ }^{150}$

\subsection{El ajuste de las decisiones-marco a los instrumentos normativos a las directivas de la Comunidad europea.}

La segunda de tales orientaciones jurisprudenciales se afirma - en perfecta sincronía con la primera - a partir de la sentencia del 13 de septiembre de $2005,{ }^{151}$ luego confirmada por la sentencia del 23 de octubre de 2007. ${ }^{152}$ En tales sentencias, la Corte de Justicia reconociendo que la materia medio ambiental es de competencia del primer pilar de la UE, y no del tercero - anuló dos decisiones-marco en materia de protección del medio ambiente a través del derecho penal, ${ }^{153}$ y estableció que los contenidos de tales decisiones-marco deben ser vertidos en instrumentos normativos del primer pilar, esto es, en directivas de la Comunidad europea. Al hacer esto, la Corte de Justicia sustancialmente afirmó que también en el ámbito de la Comunidad europea (la que constituye, por así decir, el núcleo primigenio de la Unión europea) pueden adoptarse textos de carácter penal. Esto implica un potenciamiento vistoso de la política criminal europea, en razón del mayor nivel de obligatoriedad o vinculación que tienen los instrumentos normativos del primer pilar con respecto a los de tercer pilar. ${ }^{154}$ Sería suficiente pensar que, mientras las decisiones-marco son adoptadas por unanimidad y que por tanto suponen el consenso previo de todos los Estados UE, las directivas del primer pilar pueden ser adoptadas incluso contra la voluntad

148 BAZZOCCHI, Valentina, "Il caso Pupino e il principio di interpretazione conforme delle decisioni quadro", Quaderni cost., 2005, p. 886. Entre otros, concuerdan con el hecho de que la sentencia Pupino constituye la expresión de la tendencia a "comunitarizar" el tercer pilar CORSTENS, Geert, "Eerste strafarrest van het Hof van Justitie over een kaderbesluit", Nederlands Tijdschrift voor Europees Recht (NTER), 2006, $\mathrm{n}^{\circ} 1 / 2$, p. 24 ; COTTE, Bruno, "L'encadrement par la norme internationale", en http://www.courdecassation.fr/IMG/File/pdf_2006/06-04-2006/06-04-06_intervention_cotte.pdf; HIJMANS, Hielke, "Le troisième pilier dans la pratique: composer avec les faiblesses. L'échange d'informations entre les États membres", en http://www.edps.europa.eu/EDPSWEB/webdav/site/mySite/shared/Documents/EDPS/Publications/Speeches/2 007/07-02-07_preadvies_NVER_FR.pdf; PRECHAL, Sacha, Juridisch cement voor de Europese Unie, Groningen: 2006, p. 22.

${ }^{149}$ Cfr. a modo de ejemplo, PICOTTI, Lorenzo, "Il Corpus Juris 2000. Profili di diritto penale sostanziale e prospettive d'attuazione alla luce del progetto di Costituzione per l'Europa", en: PICOTTI, Lorenzo (coord.), Il Corpus juris 2000. Nuova formulazione e prospettive di attuazione, Padua: 2004, pp. 62 y ss. y, en particular, p. 72.

${ }^{150}$ Como se ha recordado supra en par. 9 , nota ${ }^{\circ} 55$, tal reforma fue realizada finalmente por el Tratado de Lisboa, el que entró en vigor el $1^{\circ}$ de diciembre de 2009 , y por tanto con posterioridad a la versión original de este escrito.

${ }^{151}$ Tribunal de Justicia de la UE, sentencia de 13 de septiembre de 2005, causa C-176/03 (Comisión contra Consejo).

152 Tribunal de Justicia de la UE, sentencia de 23 de octubre de 2007, causa 440/05 (Comisión contra Consejo).

${ }^{153}$ Decisión marco 2003/80/GAI.

${ }^{154}$ Cfr., supra, par. 5. 


\section{BERNARDI, ALESSANDRO. "Seguridad y Derecho Penal en Italia y en la Unión Europea".}

de algunos países miembros, los que permanecen igualmente obligados a dar aplicación a las normas contenidas en dichas directivas. ${ }^{155}$

En este contexto resulta pertinente mencionar el hecho de que la orientación jurisprudencial en examen anticipa, de hecho, la reforma de la Unión Europea asociada al Tratado de Lisboa de diciembre de 2007, aún no en vigor, en cuanto hasta ahora ha sido ratificado sólo por 24 de los 27 Estados miembros de la UE. ${ }^{156}$ Conforme a este Tratado, la Unión europea cesará de estar dividida en tres pilares caracterizados por instrumentos normativos diferentes y específicos, y por tanto - por lo que aquí interesa - podrá crear directivas de carácter penal en todos los sectores normativos hasta ahora disciplinados por decisionesmarco del tercer pilar. Evidentemente, una vez entrado en vigencia el Tratado de Lisboa, no podrán ya adoptarse nuevas convenciones o nuevas decisiones marco en el ámbito de la Unión Europea, permaneciendo aplicables sólo los reglamentos y las directivas.

Por lo que atañe específicamente a las consecuencias en el plano de la seguridad de tal jurisprudencia y de las reformas a la Unión europea por ella anticipadas, bastará destacar aquí que ambas contribuyen a incentivar el desarrollo progresivo de una política europea de la seguridad de carácter unitario, ${ }^{157}$ en cuanto tal, destinada a resultar más eficaz, pero también más respetuosa de los derechos fundamentales. ${ }^{158}$

\subsection{La primacía de los derechos fundamentales recepcionados por la UE por sobre cualquier tipo de texto normativo limitativo de tales derechos.}

La tercera y última de estas orientaciones jurisprudenciales se ha concretizado en la recientísima y ya "histórica" sentencia de 3 de septiembre de $2008,{ }^{159}$ la que establece la primacía de los derechos fundamentales recepcionados por la Unión Europea, por sobre cualquier tipo de texto normativo limitativo de tales derechos, aun si encaminado a recepcionar resoluciones adoptadas por el Consejo de Seguridad de las Naciones Unidas a nombre de la seguridad y de la lucha contra el terrorismo. En realidad, se trata de una sentencia que vuelca la orientación interpretativa ya varias veces acogida por el Tribunal de primera instancia de la Unión Europea, ${ }^{160}$ según el cual no debían considerarse ilegítimos

\footnotetext{
${ }^{155}$ Los Estados de la UE pueden ser condenados por el Tribunal de Justicia de la UE en caso de falta de recepción o de recepción inadecuada de las directivas; la condena puede incluso implicar sanciones pecuniarias de gran entidad; cfr. art. 228 del Tratado CE.

${ }^{156}$ Como ha sido ya recordado varias veces, el Tratado entró finalmente en vigor el $1^{\text {o }}$ de diciembre de 2009 , después de que el último de los 27 países miembros lo hubo ratificado.

${ }^{157}$ Con respecto al cual cfr., ampliamente, DUTHEIL DE LA ROCHERE, Jacqueline, Vers une conception nouvelle de la sécurité européenne, cit. nota $\mathrm{n}^{\circ} 27, \mathrm{pp} .5 \mathrm{y}$ ss.

${ }^{158}$ Antes que nada, en razón de la generalización de los profundos controles jurisprudenciales relativos a la conformidad de los actos normativos de la Unión Europea con los derechos fundamentales; controles actualmente reservados sólo para los actos normativos del "primer pilar".

159 Tribunal de Justicia de la Unión Europea, Gran Sala, sentencia de 3 de septiembre de 2008, causas agrupadas C-402/05 P y C-415/05 P (Kadi y Al Barakaat International Foundation contra Consejo y Comisión).

160 Sentencias del 21 de septiembre de 2005, en el ámbito de las causas T-306/01 (Yusuf y Al Barakaat International Foundation/Consejo y Comisión) y T-315/01 (Kadi/Consejo y Comisión). En el mismo sentido, sentencia del Trib. I grado de 12 de julio de 2006, causa T-253/02 (Ayadi contra Consejo)
} 
algunos instrumentos normativos UE (en la especie, algunos reglamentos CE, ${ }^{161}$ como tales, directamente aplicables en los Estados UE) que preveían la aplicación de medidas de carácter fuertemente aflictivas (en particular, la congelación de bienes) en desmedro de quienes aparecieren inscritos en las denominadas blacklists. Se alude a las listas de los sujetos y de los entes considerados implicados en actos de terrorismo, o respecto de los cuales se sospechaban vínculos con grupos terroristas.

Pues bien, considerando que sobre la base de dichos reglamentos los procedimientos de inscripción en (y de cancelación de) las listas en cuestión no preveían un derecho de defensa ni, más en general, la posibilidad de acceso a un juez y las garantías del justo proceso, ${ }^{162}$ los recurrentes del caso pedían la anulación de tales reglamentos en razón de su falta de correspondencia con los estándares de tutela mínima de los derechos fundamentales. Sin embargo, el Tribunal UE de primera instancia había rechazado tal solicitud, afirmando la imposibilidad de los órganos de justicia UE de controlar actos de la Unión Europea encaminados a recepcionar las resoluciones del Consejo de Seguridad de la ONU; ello, en razón de la presunta primacía del ordenamiento jurídico internacional por sobre el ordenamiento jurídico de la Unión Europea; por tanto, de las mencionadas resoluciones por sobre los textos normativos $\mathrm{UE} / \mathrm{CE} .{ }^{163}$

Lo cierto es que esta orientación jurisprudencia había suscitado fuertes críticas en doctrina. ${ }^{164}$ Por lo demás, no existía duda alguna sobre la contrariedad de los reglamentos en cuestión con respecto a los derechos fundamentales reconocidos por la Unión Europea. Tanto es así que el propio Tribunal UE de primera instancia ${ }^{165}$ había considerado una decisión comunitaria de inserción en las "listas negras" como ilegítima por violación de los derechos de defensa, en el caso en el que "el interesado no haya tenido conocimiento de las acusaciones en su contra, no haya sido oído en el curso del procedimiento y que, como consecuencia de una motivación de la resolución carente de los elementos específicos y concretos que justificaron su inserción en la lista de sospechosos, no se haya encontrado en condiciones de hacer valer sus argumentos ante los tribunales". ${ }^{166}$ Sin embargo, se trataba

${ }^{161}$ Cfr. LABAYLE, Henri, “L’espace pénal européen: instrument ou objectif?”, cit. nota n 44, pp. 23 y ss.

${ }^{162}$ Cfr., por todos, DUTHEIL DE LA ROCHËRE, Jacqueline, Vers une conception nouvelle de la sécurité européenne, cit. nota $n^{\circ} 27$, p. 24 ; LORENZON, "Terrorismo, diritti fondamentali e integrazione europea: parametro fugit" en: LORENZON, Sara, VACCAI, Giulia \& ZANETTI Viviana (coords.), Sicurezza collettiva e diritti fondamentali in tempo di terrorismo, Roma: 2008, pp. 247 y ss.

${ }^{163}$ Sobre el punto cfr., para detalles adicionales, CERINI, Sandro, "“Blacklisting” e diritti fondamentali: una difficile convivenza (nella giurisprudenza del Tribunale europeo di primo grado)", en: Sicurezza collettiva e diritti fondamentali in tempo di terrorismo, cit. nota ${ }^{\circ} 162$, pp. 183 y ss.

${ }^{164}$ Cfr., entre otros, DUTHEIL DE LA ROCHÈRE, Jacqueline, Vers une conception nouvelle de la sécurité européenne, cit. nota $\mathrm{n}^{\circ} 27$, pp. 25 y ss.; SCIARABBA, Vincenzo, "I diritti e i principi fondamentali nazionali ed europei e la problematica comunitarizzazione delle risoluzioni antiterrorismo dell'ONU", Rassegna forense, 2006, pp. 147 y ss.; PILI, Giulia, "Comunitarizzazione delle risoluzioni ONU vs controlimiti”, Diritto pubblico comparato ed europeo, 2006, pp. 1232 y ss.

165 Sentencia de 12 de diciembre de 2006, causa T-228/02 (Organisation des Modjahedines du peuple de l'Iran contra Consejo UE).

${ }^{166}$ Terrorismo, listing e diritti umani, en Europeanrights.eu, Observatorio sobre el respeto de los derechos fundamentales en

Europa, http://cc.msnscache.com/cache.aspx?q=\%22terrorismo+listing+e+diritti + umani $\% 22 \& d=74336839026152 \& \mathrm{~m}$ $\underline{\mathrm{kt}=\mathrm{es}-\mathrm{CL} \& \text { setlang }=\mathrm{es}-\mathrm{CL} \& \mathrm{w}=\mathrm{a} 4 \mathrm{ea} 35 \mathrm{ae}, \mathrm{f} 7 \mathrm{e} 16 \mathrm{~b} 25}$ 
en este caso de actos emanados por la Unión Europea por vía autónoma y no en cambio en actuación de resoluciones del Consejo de Seguridad de la ONU. De hecho, en este último caso, como se ha dicho antes, el Tribunal UE de primer grado sostuvo la existencia de una suerte de "inmunidad" jurisdiccional ${ }^{167}$ en virtud de la ya mencionada primacía de las “obligaciones ONU” por sobre los actos de la Unión Europea.

Ahora bien, como se había anticipado, la sentencia del 3 de septiembre de 2008 - sobre la base de argumentos muy complejos, atinentes a las relaciones existentes entre derecho internacional y derecho europeo - invierte la tesis del Tribunal UE de primer grado, afirmando "el principio conforme al cual, todos los actos comunitarios deben respetar los derechos fundamentales". ${ }^{168}$ En consecuencia, la Corte declara su competencia para controlar la legitimidad de todos los actos normativos del primer pilar - incluidos aquellos dirigidos a la ejecución de resoluciones del Consejo de Seguridad de la ONU - en relación con los derechos fundamentales que integran los principios generales del derecho europeo.

Como ha sido observado de manera precisa, de la sentencia se desprende el reconocimento de los jueces europeos del doble rol desempeñado por el ejercicio jurisdiccional; ello en cuanto, por una parte, aparece como instrumento de oposición contra actividades criminales (de las de tipo terrorista, en primer lugar) y, por la otra, como instrumento de tutela de derechos fundamentales. ${ }^{169}$ Por tanto, para la Corte de Justicia el "derecho a la seguridad frente a la criminalidad" debe conjugarse con el "derecho a la seguridad del particular frente a los poderes públicos"; en otras palabras, debe conjugarse con los derechos y con las libertades individuales, sacrificables sólo en los casos en los que ellos no sean absolutamente intangibles (como en cambio es el caso de la prohibición de la tortura o tratamientos inhumanos) y en la medida en que resulte estrictamente necesario, según los específicos criterios de las sociedades democráticas. Lo anterior presupone un complejo juicio de balance entre la función de prevención y la de tutela de los derechos, siendo ambas funciones propias tanto de la Unión Europea como de los países UE.

\section{Consideraciones conclusivas.}

En todos los momentos en los que la alarma social suena fuerte contra formas de delincuencia especialmente peligrosas para las instituciones, la colectividad y los particulares, el "derecho a la seguridad frente a los poderes públicos" tiende a pasar a segundo plano, cediendo paso al "derecho a la seguridad frente a la criminalidad". Con ello se vuelve al concepto primigenio de seguridad como límite a los derechos y a las libertades individuales. Con frecuencia - mirado en restrospectiva - uno se percata que, en el intento

\footnotetext{
${ }^{167}$ Cfr., ampliamente, POLLICINO, Oreste \& SCIARABBA, Vincenzo, "Misure antiterrorismo: la Corte di giustizia riafferma $i$ diritti e principi fondamentali europei ribaltando una sentenza del Tribunale di primo grado (a commento della sentenza del 3 settembre 2008, C-402/05 $P$ e $C-415 / 05 \quad P$ ), en http://www.associazionedeicostituzionalisti.it/giurisprudenza/cortecostdecisioni2/corte_giustiziaCE/pollicino sciarabba.html

${ }_{168}^{168}$ Tribunal de Justicia, sentencia de 3 de septiembre de 2008, cit. nota $n^{\circ} 159$, punto 285 .

169 Cfr., ampliamente, BALSAMO, Antonio; DE AMICIS, Gaetano, "Terrorismo internazionale, congelamento dei beni e tutela dei diritti fondamentali nell'interpretazione della Corte di giustizia", Cass. Pen., 2009, pp. 401 y ss.
} 
Polit. crim. Vol. 5, No 9 (Julio 2010), Art. 2, pp. 68-113.

[http://www.politicacriminal.cl/Vol_05/n_09/Vol5N9A2.pdf]

de dar vida a un "derecho penal de lucha anti-criminal" realmente eficaz, los límites introducidos han ido más allá de lo estrictamente necesario.

Por lo que se refiere a cuán lejos deba irse en el camino de la compresión de los derechos individuales con miras a la seguridad colectiva, las opiniones son obviamente discordantes. Creo que el principio democrático prohibe a toda persona imponer verdades como definitivas e indiscutibles, constituyendo la esencia misma de la democracia la discusión, la fatigosa búsqueda de instancias de mediación a partir de puntos de vista a veces muy diversos.

Pero democracia significa también, por definición, rechazo de la dictadura y del uso de métodos "dictatoriales", aun si en honor de la más justa de las causas, como puede ser precisamente la lucha contra las formas más feroces de delincuencia. Al respecto, en Europa la Convención europea de los derechos del hombre (a la que adhieren todos los Estados europeos) considera absolutamente inderogables, en particular, el derecho a no ser sometido a tortura o a tratamientos inhumanos y degradantes (art. 3) y el derecho a no ser reducido a esclavitud (art. 4). ${ }^{170}$

Además, las más prestigiosas Cortes europeas nos recuerdan que, mientras el terrorismo agrede "sólo" a particulares o a grupos de individuos, las normas liberticidas atentan no sólo contra los derechos de los particulares, sino contra la misma supervivencia del Estado democrático y de sus valores; ${ }^{171}$ y nos recuerdan también que por razones de seguridad pública no pueden sacrificarse jamás el derecho a la vida y la dignidad humana. ${ }^{172}$

Ciertamente, los otros derechos y libertades pueden ser, por el contrario, más o menos limitados en nombre de la lucha a la criminalidad; pero siempre después de un cuidadoso balance de costos y beneficios, calibrado conforme a los principios de proporcionalidad y razonabilidad. Se trata de un balance sobre cuya congruencia las Cortes constitucionales en su rol de "jueces de las leyes" - están llamadas a pronunciarse.

${ }^{170}$ Cfr., por todos, PALAZZO, Francesco \& BERNARDI, Alessandro, La Convenzione europea dei diritti dell'uomo e la politica criminale italiana: intersezioni e lontananze, cit. nota $\mathrm{n}^{\circ} 2$, p. 40; VIGANÒ, Francesco Terrorismo, guerra e sistema penale, cit. nota $n^{\circ}$ 60, p. 697.

${ }^{171}$ Cfr. la sentencia de la House of Lords del Reino Unido del 16 de diciembre de 2004: [2004] UKHL () 56, $A(F C)$ and others $(F C)$ (Appellants) v. Secretary of State for the Home Department (Respondent), $X(F C)$ and another (FC) (Appellants) v. Secretary of State for the Home Department (Respondent), en http://www.bailii.org/uk/cases/UKHL/2004/56.html. Esta sentencia ha sido objeto de innumerables comentarios. Cfr., por lo que se refiere a Italia, BASSU, Carla, "La Camera dei Lords giudica illegittima la legislazione britannica anti-terrorismo", en http://www.associazionedeicostituzionalisti.it/cronache/estero/lords_terrorismo/index.html; BIN, Roberto, Democrazia e terrorismo, cit. nota ${ }^{\circ} 4$, pp. 45 y ss.

${ }^{172}$ Cfr. Bundesverfassungsgericht (Tribunal Constitucional de Alemania), sentencia de 15 de febrero de 2006, en http://www.bverfg.de/entscheidungen/rs20060215_1bvr035705.html. También esta sentencia ha sido objeto de numerosos comentarios. Cfr., por lo que se refiere a Italia, BIN, Roberto, Democrazia e terrorismo, op. cit. nota ${ }^{\circ} 4$, pp. 47 y ss.; DE PETRIS, Andrea, "Tra libertà e sicurezza prevale la dignità umana, dice il Bundesverfassungsgericht", en www.associazionedeicostituzionalisti.it/cronache/estero/liberta_sicurezza /index.html; PANARA, Carlo, "I dilemmi del dopo 11 settembre: l'abbattimento "preventivo" degli aerei usati per attacchi suicidi è compatibile con la tutela costituzionale del diritto alla vita? Una risposta parzialmente negativa viene dal Bundesverfassungsgericht", Giurisprudenza costituzionale, 2006, pp. 1793 y ss. 
Estos son hoy los resultados más significativos del debate sobre las relaciones entre seguridad y derecho penal que ha visto implicadas a las legislaciones y jurisdicciones de toda Europa: un continente que en el curso de su historia milenaria ha conocido regímenes políticos, leyes y jueces de toda clase, aun de las peores posibles; pero que desde hace 60 años vive en la paz y en el empeño por la progresiva construcción de organizaciones transy supra-nacionales, dirigidas al reforzamiento de las relaciones de hermandad entre los países miembros. Como hemos visto, ellas son el Consejo de Europa y la Unión Europea; esta última, en particular, dotada de múltiples competencias y tendiente a orientar las decisiones políticas nacionales en el campo de la lucha contra la criminalidad organizada, salvaguardando al mismo tiempo los derechos fundamentales. El futuro nos dirá si el período actual ha sido un fugaz y feliz paréntesis en el marco de una turbulenta historia europea o, por el contrario, una etapa fundamental del progreso de su civilización.

\section{BIBLIOGRAFÍA}

AA.VV., Le misure di prevenzione, Milán: 1975.

AA.VV., Studi in onore di B. Petrocelli, III, Milán: 1972.

ADAM, Roberto, "La cooperazione in materia di giustizia e affari interni tra comunitarizzazione e metodo intergovernativo", en: Dir. Un. Eur., 1998.

AMNESTY INTERNATIONAL, Voli segreti. Il rapporto del Consiglio d'Europa sulle operazioni coperte della CIA negli Stati Uniti, Turín: 2006.

ANGELINI, Francesca, Ordine pubblico e integrazione costituzionale europea, Padua: 2007.

AYALA, Giuseppe, Chi ha paura muore ogni giorno. I miei anni con Falcone e Borsellino, Milán: 2008.

BALSAMO, Antonio; DE AMICIS, Gaetano, "Terrorismo internazionale, congelamento dei beni e tutela dei diritti fondamentali nell'interpretazione della Corte di giustizia", Cass. Pen., 2009.

BARBAGLI, Marzio, (coord), Perché è diminuita la criminalità negli Stati Uniti?, Boloña: 2000.

BARILE, Paolo, Diritti dell'uomo e libertà fondamentali, Boloña: 1984.\}

BARTOLE, Sergio, CONFORTI, Benedetto, RAIMONDI; Guido, (dir.), Commentario della Convenzione europea dei diritti dell'uomo, Padua: 2001.

BASSU, Carla, "La Camera dei Lords giudica illegittima la legislazione britannica antiterrorismo", http://www.associazionedeicostituzionalisti.it/cronache/estero/lords_terrorismo/index. html

BAZZOCCHI, Valentina, "Il caso Pupino e il principio di interpretazione conforme delle decisioni quadro", Quaderni cost., 2005.

BECK, Ulrich, La società del rischio, Roma: 2000.

BERNARDI, Alessandro, "Il ruolo del terzo pilastro UE nella europeizzazione del diritto penale. Un sintetico bilancio alla vigilia della riforma dei Trattati”, Rivista italiana di diritto pubblico comunitario, 2007.

BIN, Roberto, BRUNELLI Giuditta, PUGIOTTO, Andrea, VERONESI, Paolo, (coord.), Ai confini del "favor rei". Il falso in bilancio davanti alle Corti costituzionale e di giustizia, Turín, 2005. 
Polit. crim. Vol. 5, No 9 (Julio 2010), Art. 2, pp. 68-113.

[http://www.politicacriminal.cl/Vol_05/n_09/Vol5N9A2.pdf]

BOLZONI, Attilio \& D'AVANZO, Giuseppe, La giustizia e cosa nostra: il caso Carnevale tra delitti e impunità, Milán: 1995

BROGGINI,Gerardo, "Le rogatorie italo-svizzere alla luce della 1. 5 ottobre 2001, n. 367", Riv. it. dir. proc. pen., 2002.

CALVANO, Roberta, "Il Caso Pupino: ovvero dell'alterazione per via giudiziaria dei rapporti tra diritto interno (processuale penale), diritto Ue e diritto comunitario", in http://www.associazionedeicostituzionalisti.it/materiali/anticipazioni/caso_pupino/ind ex.html

CAPPELLETTI, Mauro, "Giustizia costituzionale soprannazionale”, Riv. dir. proc., 1978.

CENCI, Piero, "Aggravante della finalità del terrorismo o di eversione dell' ordine democratico", Giur. merito, 1983.

CHIAVARIO, Processo e garanzie della persona, Milán, 1984.

CHITI, Edoardo \& MATTARELLA, Bernardo Giorgio, "La sicurezza europea", Rivista trimestrale di diritto pubblico, 2008.

CORDA, Mario, Corrado. L'incredibile storia del giudice Carnevale, Milán: 2008.

CORSTENS, Geert, "Eerste strafarrest van het Hof van Justitie over een kaderbesluit", Nederlands Tijdschrift voor Europees Recht (NTER), 2006.

COTTE, Bruno, "L'encadrement par la norme internationale", en http://www.courdecassation.fr/IMG/File/pdf_2006/06-04-2006/06-04-

06_intervention_cotte.pdf

CURI, Ūmberto, \& PALOMBARINI, Giovanni, (coord.), Diritto penale minimo, Roma: 2002.

CURTIN, D.M., POUW, J.M.F., "La coopération dans le domaine de la justice et des affaires intérieures au sein de l'Union européenne: une nostalgie d'avant Maastricht?", Rev. Marché un. eur., 1995.

DAVIGO, Piercamillo, MANNOZZI, Grazia, La corruzione in Italia. Percezione sociale e controllo penale, Roma-Bari: 2007.

DE FRANCESCO, Giovannangelo, "Dogmatica e politica criminale nei rapporti tra concorso di persone ed interventi normativi contro il crimine organizzato", Riv. it. dir. proc. pen., 1994.

DE MAGLIE, Cristina; SEMINARA, Sergio (coord.), Terrorismo internazionale e diritto penale, Padua: 2007.

DE PETRIS, Andrea, "Tra libertà e sicurezza prevale la dignità umana, dice il Bundesverfassungsgericht", www.associazionedeicostituzionalisti.it/cronache/estero/liberta_sicurezza/index.html

DELMAS-MARTY, Mireille, PIETH Mark, SIEBER, Ulrich, (coord.), Les chemins de l'harmonisation pénale, Paris: 2008.

DI GIOVINE, Ombretta, "Il sindacato di ragionevolezza della Corte costituzionale in un caso facile", Riv. it. dir. proc. pen., 2007.

DOLCINI, Emilio, MARINUCCI, Giorgio, “Costituzione e politica dei beni giuridici”, Riv. it. dir. proc. pen., 1994.

DONINI, Massimo, "Sicurezza e diritto penale", Cassazione penale, 2008.

DONINI, PAPA (coord.), Diritto penale del nemico. Un dibattito internazionale, Milán: 2007.

DUTHEIL DE LA ROCHERE, Jacqueline, "Vers une conception nouvelle de la sécurité européenne", Rivista italiana di diritto pubblico, 2008. 
BERNARDI, ALESSANDRO. "Seguridad y Derecho Penal en Italia y en la Unión Europea".

FALCONE, Anna, FALCONE, Maria, ZINGALES, Leone, Giovanni Falcone, un uomo normale, 2007.

FAVA, Claudio, Quei bravi ragazzi, Milán: 2007.

FENECH, Georges, Tolleranza zero, Milán: 2001.

FERRAJOLI, Luigi, Principia iuris, vol. II, Teoria della democrazia, Bari - Roma: 2007.

FERRAJOLI, Luigi, "Sul diritto penale minimo (risposta a Giorgio Marinucci e a Emilio Dolcini)", Foro it., 2000.

FIORE, I reati di opinione, Padova: 1972.

GAMBERINI, Alessandro, ORLANDI, Renzo (coord.), Delitto politico e diritto penale del nemico, Boloña: 2007.

GIUNTA, Fausto, “L. 16 febbraio 1995, n. 36 - Proroga delle disposizioni di cui all'art. 41 bis 1.26 luglio 1975, n. 354, sulla sospensione delle normali regole di trattamento penitenziario", La legislazione penale, 1996.

GIUPPONI, Tommaso F. "Stato di diritto e attività di intelligence: gli interrogativi del caso Abu Omar”, Quaderni costituzionali, 2006.

GRASSO, Giovanni, (coord.), La lotta contro la frode agli interessi finanziari della Comunità europea tra prevenzione e repressione, Milán: 2000.

HIJMANS, Hielke, "Le troisième pilier dans la pratique: composer avec les faiblesses. L'échange d'informations entre les États membres", en http://www.edps.europa.eu/EDPSWEB/webdav/site/mySite/shared/Documents/EDPS/ Publications/Speeches/2007/07-02-07_preadvies_NVER_FR.pdf

INSOLERA, Gaetano, "Ordine pubblico e ordine democratico: le stagioni dell'emergenza", Critica del diritto, gennaio-marzo 2003.

KOSTORIS, Roberto E., ORLANDI, Renzo (coord.), Contrasto al terrorismo interno e internazionale, Turín: 2006.

LA LICATA, Francesco, Storia di Giovanni Falcone, Milán: 2003.

LORENZON, Sara, VACCAI, Giulia \& ZANETTI Viviana (coords.), Sicurezza collettiva e diritti fondamentali in tempo di terrorismo, Roma: 2008.

LUCENTINI, Umberto, Paolo Borsellino. Il valore di una vita, Milán: 1994.

MANACORDA, Stefano, "Judicial activism dans le cadre de l'Espace de liberté, de justice et de sécurité de l'Union européenne", Revue de science criminelle et de droit pénal comparé, 2005.

MANACORDA, Stefano, “L'armonizzazione dei sistemi penali: una introduzione”, en: La giustizia penale italiana nella prospettiva internazionale, Milano: 2000.

MANES, Vittorio, "I rapporti tra diritto comunitario e diritto nazionale nello specchio della giurisprudenza della Corte di giustizia: approdi recenti e nuovi orizzonti”, en ius17@unibo.it

MARGUE, Tung Lai, "La coopération en matière de prévention et de lutte contre le crime dans le cadre du nouveau troisième pilier", Rev. dr. Un. eur., 2000.

MASTROIANNI, Roberto, "Il controllo della Corte di giustizia in relazione agli atti del I e del III pilastro: riflessi in materia penale", en http://appinter.csm.it/incontri/relaz/9908.pdf

MASTROIANNI, Roberto, "La sentenza della Corte cost. n. 39 del 2008 in tema di rapporti tra leggi ordinarie e CEDU: anche le leggi cronologicamente precedenti vanno rimosse dalla Corte costituzionale?", http://www.giurcost.org/decisioni/index.html 
Polit. crim. Vol. 5, No 9 (Julio 2010), Art. 2, pp. 68-113.

[http://www.politicacriminal.cl/Vol_05/n_09/Vol5N9A2.pdf]

MOCCIA, Sergio, La perenne emergenza. Tendenze autoritarie nel sistema penale, Nápoles: 1995.

MODUGNO, Franco, I "nuovi diritti" nella giurisprudenza costituzionale I "nuovi diritti" nella giurisprudenza costituzionale, Turín: 1995.

MOROSINI, Piergiorgio, Il concorso di persone e le organizzazioni complesse, ponencia realizada el 29 de octubre de 2008 con ocasión del encuentro de estudios penales organizado en Roma por el Consejo Superior de la Magistratura (CSM) desde el 27 al 31 de octubre de 2008.

MOSCARINI, Paolo, "In tema di reati commessi per finalità di terrorismo o d' eversione", Giur. it., 1982.

O'KEEFFE, David, "Recasting the Third Pillar", Common Market Law Review, 1995.

ORTEGA ÁLVAREZ, Luis, (coord.), La seguridad integral europea, Valladolid: 2005.

PACE, Alessandro, "Il concetto di ordine pubblico", Arch. Giur., 1963

PADOIN, Paolo, "La sicurezza nelle città: città inclusiva, città sicura", Nuova rassegna di legislazione, dottrina e giurisprudenza, 2006.

PADOVANI, Tullio, "La soave inquisizione. Osservazioni e rilievi a proposito delle nuove ipotesi di "ravvedimento"", Riv. it. dir. proc. pen., 1981.

PALAZZO, Francesco, Corso di diritto penale. Parte generale, Turín: 2008.

PALAZZO, Francesco, La recente legislazione penale, Padua: 1980.

PALAZZO, Francesco; BERNARDI, Alessandro, "La Convenzione europea dei diritti dell'uomo e la politica criminale italiana: intersezioni e lontananze", Rivista internazionale dei diritti dell'uomo, 1988.

PANARA, Carlo, "I dilemmi del dopo 11 settembre: l'abbattimento "preventivo" degli aerei usati per attacchi suicidi è compatibile con la tutela costituzionale del diritto alla vita? Una risposta parzialmente negativa viene dal Bundesverfassungsgericht", Giurisprudenza costituzionale, 2006.

PAVARINI, Massimo, "Vecchia”e "Nuova "legalità", Critica del diritto, 2003.

PEPINO, Livio, "La città e l'impossibile supplenza giudiziaria", Questione giusitizia, 1999.

PICOTTI, Lorenzo (coord.), Il Corpus juris 2000. Nuova formulazione e prospettive di attuazione, Padua: 2004.

PILI, Giulia, "Comunitarizzazione delle risoluzioni ONU vs controlimiti”, Diritto pubblico comparato ed europeo, 2006.

PIZZIMENTI, Eugenio; VANNUCCI, Alberto, "Il concetto di sicurezza e le politiche per la sicurezza", Riv. trim. scienza amm., 2005.

POLLICINO, Oreste \& SCIARABBA, Vincenzo, "Misure antiterrorismo: la Corte di giustizia riafferma $i$ diritti e principi fondamentali europei ribaltando una sentenza del Tribunale di primo grado (a commento della sentenza del 3 settembre 2008, C$\begin{array}{llllll}\text { 402/05 } P & e & C-415 / 05 & P \text { ), }\end{array}$ http://www.associazionedeicostituzionalisti.it/giurisprudenza/cortecostdecisioni2/cort e giustiziaCE/pollicino sciarabba.html

PRECHAL, Sacha, Juridisch cement voor de Europese Unie, Groningen: 2006.

PULITANò, Domenico, "Obblighi costituzionali di. tutela penale?", Riv. it. dir. proc. pen., 1983.

RAFARACI, Tommaso (coord.), L'area di libertà, sicurezza e giustizia. Alla ricerca di un equilibrio tra priorità di sicurezza ed esigenze di garanzia, Milán: 2007. 
BERNARDI, ALESSANDRO. "Seguridad y Derecho Penal en Italia y en la Unión Europea".

RAIMONDI, Salvatore, "Per 1'affermazione della sicurezza pubblica come diritto", Dir. Amm., 2006.

RUOTOLO, Marco, "Quando l'emergenza diventa quotidiana. Commento alle modifiche agli artt. 4-bis e 41-bis dell'ordinamento penitenziario", Studium iuris, 2003.

SALAZAR, Lorenzo, "La costruzione di uno spazio di libertà, sicurezza e giustizia dopo il Consiglio europeo di Tampere", Cass. pen., 2000.

SALERNO, Francesco, (coord.), Diritti dell'uomo, estradizione ed espulsione, Padua: 2003.

SAVARESE, Eduardo, "Cooperazione giudiziaria e garanzie processuali, con particolare riguardo all'utilizzabilità del materiale probatorio acquisito in esecuzione di commissioni rogatorie, alla luce della 1. 5 ottobre 2001, n. 367", Giur. it., 2003.

SECCHI, Zaira, "Rogatorie con la Svizzera: risposta italiana alle attività transnazionali della criminalità (lucido disegno o confusione mentale?)", Questione giustizia, 2002.

SCIARABBA, Vincenzo, "I diritti e i principi fondamentali nazionali ed europei e la problematica comunitarizzazione delle risoluzioni antiterrorismo dell'ONU", Rassegna forense, 2006.

SCIARABBA, Vincenzo, "Il problema dei rapporti tra (leggi di esecuzione di) vincoli internazionali e leggi precedenti nel quadro della recente giurisprudenza costituzionale, http://www.giurcost.org/decisioni/index.html

VAN DE KERCHOVE \& WEYEMBERGH, Anne, (coord.), Sécurité et justice: enjeu de la politique extérieure de l'Union européenne, Bruxelles: 2003.

VASSALLI, Giuliano (coord.), Dizionario di diritto e procedura penale, Milán: 1986.

VIGANÒ, Francesco, "Terrorismo, guerra e sistema penale”, Riv. it. dir. proc. pen., 2006.

ZAFFARONI, Raúl, El enemigo en el derecho penal, Buenos Aires: 2007.

ZINGALES, Leone, Paolo Borsellino - una vita contro la mafia, Arezzo: 2005. 